\title{
The Practical Soul of Business Ethics: The Corporate Manager's Dilemma and the Social Teaching of the Catholic Church
}

\author{
Leo L. Clarke, ${ }^{\dagger}$ Bruce P. Frohnen, ${ }^{\ddagger} \&$ Edward C. Lyons ${ }^{*}$
}

\section{INTRODUCTION}

When the twenty-first century opened with a spate of corporate swindles and scandals, ${ }^{1}$ the American public demanded renewed

$\dagger$ Leo L. Clarke, Associate Professor, Thomas M. Cooley Law School. B.A. in Economics with distinction from Stanford University; J.D., UCLA Law School.

$\ddagger$ Bruce P. Frohnen, Associate Professor, Ave Maria School of Law. J.D., Emory University; Ph.D., Cornell University.

* Edward C. Lyons, Assistant Professor, Ave Maria School of Law. J.D., Notre Dame Law School; M.A., Ph.D., University of St. Thomas.

1. The scandals involving Enron, WorldCom, and Tyco are just three of the most famous examples. Enron, a Houston-based energy firm, became the world's largest energy trading company and the seventh largest corporation in America, before it filed for bankruptcy on December 2, 2001, days after its stock was downgraded to "junk." Right up until the last week before it declared bankruptcy, reputable firms such as Goldman Sachs, UBS Warburg, and Lehman had buy or hold recommendations on its stock. This was largely due to the way Enron manipulated its annual reports, particularly its earnings per share (EPS), by selling off assets to off-balance sheet entities which Enron itself had created. Enron's Bankruptcy-Wasted Energy, THE ECONOMIST (North America), Dec. 6, 2001, at 13.

WorldCom was a re-seller of long-distance telephone services and became one of the world's largest internet firms. In April of 2002 its share price tumbled when massive fraud was discovered over the previous five quarters, it had "misclassified over $\$ 4$ billion of telecoms-maintenance costs as capital spending that could be depreciated over several years, not one." WorldCom filed for bankruptcy and its two most senior financial officers were charged with fraud. WorldComAccounting for Change, ECONOMIST (North America), June 27, 2002, at 13.

Dennis Kozlowski, CEO of Tyco, turned the obscure New England electronics firm into a high-power conglomerate. Kozlowski earned $\$ 30$ million dollars in 2001, Tyco's Troubles-Taxing Times, ECONOMIST (North America), Jun. 8, 2002, at 71, yet had Tyco contribute \$2.5 million towards his mansion, the purchase of a yacht, and his wife's $\$ 2$ million birthday party. Opinion, Chief Executives-Humbled, ECONOMIST.COM, (Dec. 18, 2003), available at http:// www.economist.com/displaystory.cfm?story_id $=2281938$.

For a list of high profile corporate scandals, see The Corporate Scandal Sheet, FORBES.COM, available at http://www.forbes.com/2002/07/25/accountingtracker_print.html (last updated Aug. 26, 2002); Corporate Scandal Quicksheet, THE CORPORATE LIBRARY, available at hitp:// www.thecorporatelibrary.com/Governance-Research/spotlight-topics/spotlight/scandals/scandalquicksheet.html (last updated Dec. 30, 2003). 
attention to business ethics. Congress immediately legislated on the matter, ${ }^{2}$ the stock market took its revenge on perceived cheaters, and regulatory and private actions proliferated. ${ }^{3}$ All of these phenomena, however, merely addressed the lowest rung on the ethical ladder: "Do not lie, cheat or steal."

This Article looks beyond the scandals and crooks to the "Manager's Dilemma" faced by those thousands of corporate officers who must choose between what their business judgment tells them is economically best for their employer and what their consciences tell them is morally right. Stride Rite, a shoe company recognized for its social commitments, provides a representative example. Faced with a difficult decision on whether to close a plant in New Bedford, Massachusetts, the Chairman of the Board commented: "Our hearts said, 'Stay' but our heads said, 'Move.", The Chairman's statement exemplifies the head/heart dilemma faced sooner or later by almost all managers. The head represents remorseless economic realities for the company and its investors. The heart represents the humane considerations often entertained as a response to those economic demands in view of the manifold consequences of company decisions on the lives of individual workers. Such dilemmas can range from Stride Rite's socially significant plant closing to the simple question of how to deal fairly with a supplier, and can include myriad factual situations from approving an advertising program to setting a pricing structure or reducing product support services. Yet, from the sublime to the ridiculous, every Manager's Dilemma begins with a situation where

2. Sarbanes-Oxley Act of 2002,15 U.S.C. $\S 7201$ (2000) (protecting investors by improving the accuracy and reliability of corporate disclosures).

3. According to Institutional Shareholder Services (ISS), which advises institutional shareholders on how to vote on proxies, 479 proposals were presented to shareholders through June 14,2002 , a $7 \%$ increase from the same period in 2001 , and of these 106 won majority votes-the highest ever tracked by ISS. Of these, the proposal that was submitted to the most companies (60 in total) demanded shareholder rights plans be submitted for a shareholder vote. Ronna Abramson, Voices in the Corporate Wilderness, THESTREET.COM, (Oct. 15, 2002), available at http://www.thestreet.com/tech/ronnaabramson/10047135.html. The Corporate and Auditing Accountability, Responsibility, and Transparency Act of 2002, "The Sarbanes-Oxley Act of 2002," created 26 provisions covering a wide range of subjects, including The Public Company Accounting Oversight Board (Title I) and independent auditor standards (Title II), mandating public companies to have audit committees (Sec. 301). 15 U.S.C. $\$ \$ 7211-46$ (2000).

4. Joseph Pereira, Split Personality: Social Responsibility and Need for Low Cost Clash at Stride Rite, WALL ST. J., May 28, 1993, at Al (quoted in Constance E. Bagley \& Karen L. Page, The Devil Made Me Do It: Replacing Corporate Directors' Veil of Secrecy with the Mantle of Stewardship, 36 SAN DIEGo L. REV. 897, 938 n.212 (1999)). Obviously, not all chief executive officers see two horns to the dilemma. As one stated, "As CEO i have a duty to do what's best for the shareholders. I can't let my own sense of right and wrong get in the way." R. EDWARD Freeman \& Daniel R. Gilbert, JR., Corporate Strategy and the Search for Ethics 23 (1988). 
economic decisions trigger the consciences of managers and employers and raise questions about moral responsibility and doing the right thing.

Our analysis focuses on and attempts to dispel an overly narrow view of the moral responsibilities of corporations and their managers. Many businessmen and lawyers, relying on prevailing approaches to business ethics, labor under the misperception that the moral ladder in the business world has only one rung: "Be honest." Americans, however, should, can and do expect more from the managers of our large corporations, and virtually every Fortune 100 company publicly espouses a "social responsibility" far exceeding mere honesty. Further, as we demonstrate, American jurisprudence is consistent with those expectations.

Our thesis is that Catholic Social Teaching provides a reliable set of principles for resolving the Manager's Dilemma because it provides a consistent basis for evaluating the human aspects of the nature and purposes of economic relationships that corporate law, business ideology and popularly accepted economic theory fail to adequately address. ${ }^{5}$ In other words, we propose a strategy for resolving head/heart dilemmas consistent with a manager's corporate fiduciary duties. In Part I, we introduce the ethical dilemma facing officers and managers in today's corporate environment. In Part II, we consider the purportedly conflicting notions of ethical responsibility imposed on a corporation and its actors, and focus on the various interpretations that have been offered in defining the scope of that ethical responsibility. In Part III, we describe the basic elements of the social teaching of the Catholic Church and the pertinent concepts of natural law philosophy that follow from and support that teaching. In particular, we argue that this social teaching can be an effective source of guidance for corporate managers wanting to synthesize their moral, ethical, and professional lives. ${ }^{6}$ Finally, in Part IV

5. By traditional economic theory, we refer to the notions of economic science recognized by advocates of what is commonly referred to as "law and economics." See R.H. COASE, THE NATURE OF THE FIRM (1937), reprinted in THE NATURE OF THE FIRM: ORIGINS, Evolution, AND DEVElopment 18-33 (Oliver E. Williamson \& Sidney G. Winter eds., Oxford Univ. Press 1991) (proposing a transaction cost approach to the theory of the firm, which refers to the comparative costs of organizing transactions through markets rather than within individual firms).

6. We use the term "Catholic Social Teaching" (CST) to refer to the teachings of the Roman Catholic Church as to matters of social and economic relationships among people and institutions. The corpus of this teaching can be found in a variety of sources including Scripture, documents promulgated by the Second Vatican Council (most particularly, Gaudium et Spes: The Constitution of the Church in the Modern World, available at http://www.vatican.va/archive/hist_councils/ ii_vatican_council/documents/vat-ii_cons_19651207_gaudium-et-spes_en.html (last visited July 17, 2005)), THE CATEChism of THE CATHOLIC CHURCH, various popes (especially Pope John Paul II) and, of interest to U.S. corporate managers, the United States Conference of Bishops. Each of these writings draws on Scripture, the Tradition of the Catholic Church, and works of moral philosophy to elucidate our moral obligations with respect to social and economic matters. While the primary 
we offer five examples of how Catholic Social Teaching would apply to specific business scenarios.

\section{THE INADEQUACY OF COMMON APPROACHES TO RESOLUTION OF ETHICAL DILEMMAS}

Whether moved by survival instinct, greed, or brotherly love, corporate directors and managers regularly face apparent zero sum decisions affecting the fortunes and futures of investors, creditors, employees, vendors, customers, neighbors, and broader communities. For every alternative course of action, there are benefits and costs, winners and losers. One alternative may often be the "best" for a given constituency of the enterprise, but doubts usually exist, given the competing interests of all stakeholders, concerning whether any one alternative is "best" overall. Further, even if the choice were limited to the impact on shareholders, managers may still have to choose between long-term shareholders, day-trading speculators, mutual fund managers, pension plan participants, and so on.

The conscientious manager may be provided with cadres of experts from disciplines as varied as engineering, economics, finance, labor relations, materials management, law, and anthropology as she considers alternative analyses, but there is little guidance available to determine the criteria for evaluating and choosing between these presumably wellanalyzed options. It is not clear under existing practice and business law where the manager is expected to look for answers to questions of what she "ought" to do.

Too often, managers - even of corporations that profess to be good corporate citizens-yield to glib substitutes for hard ethical analysis. One common placebo is to graciously forsake short-term profits for long-term profits. $^{7}$ While it has never been widely believed that corporate fiduciaries must maximize short-term profits, ${ }^{8}$ the strength of the profit-

audience for this teaching is the Roman Catholic faithful, many of the documents are addressed to all men of goodwill and thus are intended to have universal application. We do not include within CST the large body of writings by other individual Christians on moral aspects of socio-economic matters since any fair treatment of those works and issues would be beyond the scope of this work.

7. For example, a manager may justify giving a valued employee extra time off for child care or for cancer treatment in violation of company policy on the ground that the company is better off in the long run by keeping that employee and signaling to other valued employees that they will be protected from unreasonable application of company work rules.

8. Katz v. Oak Indus., 508 A.2d 873,879 (Del. Ch. 1986) ("It is the obligation of directors to attempt, within the law, to maximize the long-run interests of the corporation's stockholders; that they may sometimes do so "at the expense" of others ... does not constitute a breach of duty."). The strongest version of the corporate duty to maximize profits entails only a duty to common shareholders, defined as the business's residual risk bearers. "Residual" risk is, in its essence, longterm, and any quandary over short versus long-term profits is essentially a conflict between the 
maximization myth has led many CEOs to insist that they are satisfying all the applicable ethical demands of being a "good corporate citizen" and "socially responsible" whenever they forego short-term profits, as long as there is a neutral or positive effect on long-term profits.

A second substitute for what we would consider to be a comprehensive ethical approach consists of limited, albeit grandiose, corporate reliance on honesty and fair dealing in transactions-practices that are certainly consistent with long-term profit-maximization, yet fail in many instances to incorporate all relevant ethical concerns. ${ }^{9}$ In fact, it often appears that such minimalist corporate ethics standards are limited, if not in essence motivated, by "market-driven" analysis, and therefore fail to demonstrate a commitment to fully ethical behavior. ${ }^{10}$ As tritely

interests of speculators/shareholders and long-term investors. See Easterbrook \& Fischel, The Proper Role of a Target's Management in Responding to a Tender Offer, 94 HARV. L. REV. 1161, 1173-74 (1981); Fischel, Efficient Capital Market Theory, the Market for Corporate Control, and the Regulation of Cash Tender Offers, 57 TEX. L. REv. 1, 3, 25-26, 45 (1978); H. R. REP. NO. 94-1373, at 12 (1976). Since only the long-term investors are true residual risk bearers, the fiduciary duty to "owners" must run to them, and the apparent conflict between maximization of short and long-term profit is essentially a false one.

9. See, e.g., Jeffrey R. Immelt, Integrity, GE, available at http://www.ge.com/en/ commitment/social/integrity (last visited Mar. 10, 2005) ("This is a company of integrity. It's a company of standards. Our worldwide reputation for honest and reliable business conduct, built by so many people over so many years, is tested and proven in each business transaction we make.); AT\&T, AT\&T's Corporate Governance Guidelines (Mar. 1, 2004), available at http://www.att.com/ir/cg/cgg.html ("Each member of the Board of Directors shall at all times exhibit high standards of integrity and ethical behavior. Each director shall adhere to the applicable Company policies concerning integrity and ethical behavior ... ."); PRG SCHULTZ, Philosophy (2003), available at http://www.prgx.com/prg_schultz/philosophy.html ("Our Values - Honesty: We believe in communicating openly, being facts-oriented and demonstrating respect for everyone associated with our organization or our clients' organizations . . . ."); FORD MOTOR CO., Overview (2003) available at http://www.ford.com/en/company/about/overview.htm ("Our Values: Our business is driven by our consumer focus, creativity, resourcefulness, and entrepreneurial spirit .... Our integrity is never compromised and we make a positive contribution to society."); SHELL, Business Principles (March 1997) available at http://www.shell.com/home/ Framework?siteld=royal-en\& $\mathrm{FC} 2=/$ royal-en/html/iwgen/environment_and_society/commitment_ policies_standards/business_principles/zzz_lhn.html\&FC3=/royal-en/html/iwgen/environment_and_ society/commitment_policies_standards/business_principles/business_principles.html ("Our Principles are part of everything we do. We have nine Principles, which apply to all our business affairs and describe the behavior expected of every employee. The Principles are based on our core values of honesty, integrity and respect for people. They also indicate how we promote trust, openness, teamwork and professionalism, and pride in what we do.").

10. Frank H. Easterbrook \& Daniel R. Fischel, The Economic Structure of CORPORATE LAW 38 (Harvard University Press 1991).

Society must choose whether to conscript the firm's strength (its tendency to maximize wealth) by changing its structure so that it is less apt to maximize wealth. The latter choice will yield less of both good ends than the former. One reason is obvious: a manager told to serve two masters (a little for the equity holders, a little for the community) has been freed of both and is answerable to neither. Faced with a demand from either group, the manager can appeal to the interests of the other. Agency costs rise and social wealth falls. 
illustrated in the popular post-war movie Miracle on $34^{\text {th }}$ Street, ${ }^{11}$ managers sometimes justify ethical business practices on the view that in the end they will actually increase profitability and consumer demand. In a similar vein, statements of company officers often seem to display a willingness to do the right thing to the extent it means sacrificing shortterm profits for long-term profits, but conceal an unwillingness to do the right thing if it actually means reducing long term profits to any material degree.

More sophisticated approaches to managerial behavior have been proposed. For example, the political right demands that managers act in accordance with notions of fiduciary duty and the tenets of neoclassical economics, specifically the economics of the firm. ${ }^{12}$ The problem with this approach, however, is that it leaves the Manager's Dilemma unresolved: It acknowledges the "head," but never addresses the manager's intuitive sense that mere economic analysis is insufficient because it ignores the "heart," i.e., the ethical demands, similar to those experienced by Stride Rite's Chairman, that go beyond the needs of the firm.

At the left end of the spectrum, structuralists would have managers' decisions dictated solely by governmental regulation. ${ }^{13}$ While a Marxist view of government involvement in business may no longer be discussed with any seriousness, today's structuralists contend that certain industries or aspects of business necessitate heavy regulation. ${ }^{14}$ This view, often

Id.

11. In the movie, a hired department store Santa begins directing customers to other stores when their prices or selection is better. His employer's sales increase as a result, which causes its competitors to also adopt and advertise their consumer-friendly ethical behavior.

12. The manager's fiduciary duties are generally the duty of care and the duty of loyalty. The duty of care is "to act as a prudent person does in the management of his own affairs of equal gravity"; the duty of loyalty is "to maximize the investors' wealth rather than one's own." EASTERBROOK \& Fischel, STRUCtURE OF CORPORATE LAW, supra note 10, at 103. "To use the fiduciary principle for any purpose other than maximizing the welfare of the investors subverts its function by turning the high costs of direct monitoring-the reasons fiduciary principles are needed - into a shield that prevents investors from controlling managers' conduct." $I$. at 93.

13. The structuralist view derives from the modern populist perspective, and is a branch of economic analysis that argues that if one can statistically show both industrial concentration and above-average profit rates for an industry, it is reasonable to infer that the firms are engaging in monopolization. Barbara Ann White, Black and White Thinking in the Gray Areas of Antitrust: The Dismantling of Vertical Restraints Regulation, 60 GEO. WASH. L. REV. 1, 2 n.6 (1991).

14. For instance, environmental regulations reflect a lack of public trust in unchecked industrial growth. Barbara A. Boczar, Toward a Viable Environmental Regulatory Framework: From Corporate Environmental Management to Regulatory Consensus, 6 DEPAUL Bus. L.J. 291, 291-92 (1994) ("Congress installed numerous command and control pieces of legislation in the early 1970s, such as the Clean Air Amendments of 1970 and the Federal Pollution Control Act of 1972 (Clean Water Act)."). The same distrust is the reason why the government so heavily regulates Chapter 11 bankruptcy. Christopher W. Frost, The Theory, Reality and Pragmatism of Corporate Governance in Bankruptcy Reorganizations, 72 AM. BANKR. L.J. 103, 108 (1998) ("But, while shareholder voting 
associated with the welfare state, ${ }^{15}$ is based on the assumption that corporations will not or cannot effectively self-regulate. Therefore, government must intervene and demand a certain standard of behavior from corporations and their managers. Such a view, ironically, has little faith in either individuals or markets. As a result, it is either totally unhelpful to the manager in those instances where no regulation applies, or is suggestive of no ethical responsibility whatever in non-regulated industries. Structuralism, therefore, offers no definitive ethical guidance to the manager.

More recently, the work of business ethicists ${ }^{16}$ and statements of principles by management groups such as the Caux Roundtable ${ }^{17}$ and the

rights and fiduciary duties may constrain managerial behavior in the most egregious circumstances, these methods are unlikely to be effective in completely assuring managerial allegiance. In addition, these methods are inadequate to assure creditors that managers will not take actions that result in insolvency of the firm."). See also Jules L. Coleman, Afterword: Symposium on Post-Chicago Law and Economics: The Rational Choice Approach to Legal Rules, 65 CHI.-KENT. L. REV. 177, 179 (1989) ("Constraints are rational for all actors only under conditions of market failure. As a result, legal rules are rational for all agents only under conditions of market failure.").

15. "The institutions of and the guarantees of entitlements to social insurance, health, state education and training, housing, assistance for families, and social assistance are basic structural assets, which are difficult simply to theorize or wish away." Robert F. Rich, Borrowing Policy: Health Policy, Health Insurance and the Social Contract, 21 COMP. LAB. L. \& POL'Y J. 397, 398 (2000).

16. See, e.g., Thomas W. Dunfee \& Timothy L. Fort, Corporate Hypergoals, Sustainable Peace, and the Adapted Firm, 36 VAND. J. TRANSNA T'L L. 563, 568 (2003) ("[A] nurturing business environment requires that its practitioners hold compatible values, particularly those associated with fundamental honesty and promise-keeping."); Thomas W. Dunfee, Challenges to Corporate Governance: Corporate Governance in a Market with Morality, 62 LAW \& CONTEMP. PROBS. 129, 157 (1999) ("Managers will more effectively satisfy their primary duty to shareholders when they respond to signals of significant moral preferences within capital, consumer, and labor markets relevant to the firm. Managers have a further obligation, based on a social contract, to act consistently with mandatory marketplace morality and manifest universal norms."); Timothy L. Fort, Corporate Makahiki: The Governing Telos of Peace, 38 AM. BUS. L.J. 301, 305 (2001) ("Creating this kind of space frequently takes the form of identifying legal rules or philosophical principles that ought to be followed in addition to, and sometimes instead of, maximization of profits. The approach thus is one that allows for maximization of profits as long as certain boundaries are not crossed."); Thomas Donaldson \& Thomas W. DunfeE, Ties THat Bind: A SOCIAl Contracts approach TO BUSINESS ETHICS (1999) (arguing that corporate leaders should use respect and tolerance to create new social contracts that reflect the rich mix of culture and religious attitudes in our global society); Susanna M. Kim, Characteristics of Soulless Persons: The Applicability of the Character Evidence Rule to Corporations, 2000 U. ILL. L. REV. 763 (2000) (arguing that the ban on the character evidence rule should not apply to corporations).

17. "The CRT Principles for Business offer a foundation for dialogue and action for business leaders worldwide and affirm the necessity for moral values in business decision-making. Without moral values, stable business relationships and a sustainable world community are impossible." CAUX ROUND TABLE, About Us (2003), available at http://www.cauxroundtable.org/english.htm:

These principles are rooted in two basic ethical ideals: kyosei and human dignity. The Japanese concept of kyosei means living and working together for the common good, enabling cooperation and mutual prosperity to coexist with health and fair competition. 
Business Roundtable ${ }^{18}$ have led to increased awareness that considerations beyond fiduciary duty, economic efficiency, and regulatory compliance should factor into the decision-making process of corporate managers. In general, these sources suggest that a manager should choose the alternative that:

1. Most efficiently allocates corporate resources, that is (a) optimizes benefit (generally measured in profit) to the corporation and (b) minimizes harm to others that can be avoided at no cost;

\section{Honors societal norms regarding ethical behavior; and}

3. Protects the economic interests of owners of equity capital over those of other stakeholders in the corporate enterprise. ${ }^{19}$

The Manager's Dilemma arises, however, precisely because prevailing law, economic theory, American business ideology, and the exhortations of business ethicists have not developed a workable formula for actually reconciling profitability (factors 1 and 3 ) with so-called "corporate responsibility" or "social justice" (factor 2). The nature of the factors identified above demonstrates why: The three elements are non-

"Human dignity" refers to the sacredness or value of each person as an end, not simply as

a mean to the fulfillment of others' purposes or even majority prescription.

CAUX ROUND TABLE, Principles for Business (2003), available at http:// www.cauxroundtable.org/documents/PrinciplesforBusiness.doc.

18. BUSINESSROUNTABLE.ORG, Corporate Governance (2003), available at http:// www.businessroundtable.org/taskForces/taskforce/issue.aspx?qs=6555BF $159 \mathrm{~F} 949514481138 \mathrm{~A} 6 \mathrm{DB}$ E7A7A19BB6487B0683A ("Ethical standards and practices in the workplace are the pillars of strong business and successful employment."); BuSINESSROUNTABLE.ORG, Corporate Ethics Brochure (2003), available at http://www.businessroundtable.org/pdf/CorpEthicsBrochure.pdf ("The Institute provides a unique opportunity for leading educators, business educators and students alike to merge the theory and practice of business together in a seamless enterprise for the common good .... Because CEOs understand that no law or regulation alone can guarantee adherence to sound principles and ethical behavior, they want to provide leadership in this area."

19. Note the term "should." We do not use "must" or similar connotations of duty because corporate managers are, except in very rare circumstances, protected by the so-called "business judgment rule" from liability for failing to follow the above suggestions. "The 'business judgment' rule sustains corporate transactions and immunizes management from liability where the transaction is within the powers of the corporation (intra vires) and the authority of management, and involves the exercise of due care and compliance with applicable fiduciary duties." HARRY G. HENN \& JOHN R. AleXANDer, Laws OF CORPORATIONS $\S 242$ (3d ed. 1983). Indeed, Daniel Fischel and Frank Easterbrook have recognized that the mandatory legal duty has become so irrelevant that the real moral quandary for the corporate manager is how far to stretch the rhetoric of profit-maximization (shareholder wealth primacy) to rationalize adoption of a course of action dictated by the manager's conscience. See Frank H. Easterbrook \& Daniel R. Fischel, Tender Offer Antitrust Suits, 80 MICH. L. REv. 1155, 1171 (1982) ("It is not true, however, that there is a legal duty to enforce every legal right. Managers may decline to enforce legal rights, because enforcement may cost the firm more than non-enforcement. Managers may contract, explicitly or implicitly, to forego enforcement of legal rights.") (internal citations omitted). 
quantifiable except in the roughest sense; they may be, and generally are, in conflict with each other and, most fundamentally, they are seldom in sync with the reality of twenty-first century business and society. ${ }^{20}$ More significantly, none of these popular sources deal with the central problem that raises itself in the manager's conscience: What about the people involved? In the absence of an analytical tool that explicitly takes into account the dignity, rights and needs of the people affected by the manager's decision, none of the ideology or theory taught by business schools can resolve the Manager's Dilemma.

In sum, fiduciary principles and economics, government regulations, and circular formulae of "business ethics" as good business cannot resolve the Manager's Dilemma because none offer assistance in resolving the conflict between what the manager perceives with her head as "good business" and what her heart insists is "good behavior."

\section{THE MORAL RESPONSIBILITY AND AUTONOMY OF CORPORATIONS AND THEIR MANAGERS}

The foregoing discussion has suggested, without directly answering, the question of whether the Manager's Dilemma is legitimate in the sense that the manager has the freedom or responsibility to listen to his heart. A corporate manager can have a moral dilemma, however, only if the following three predicates are satisfied:

1. The corporation itself has moral responsibility;

2. The manager has moral responsibility; and

20. See, e.g., Adam Winkler, Case Studies in Conservative and Progressive Legal Orders: Corporate Law or the Law of Business? Stakeholders and Corporate Governance at the End of History, 67 LAW \& CONTEMP. PROBS. 109, 112 (2004):

Whatever its explanatory power in corporate law, shareholder primacy is far from an accurate description of the law of business or of corporate practice. After a century of regulation outside of corporate law, progressives have found numerous ways to enhance the social responsibility of corporations and protect the workers, consumers, and communities affected by corporate behavior. Free market principles and shareholder primacy have not won the day; they exist in corporate law alongside the many other areas of the law of business that do interfere with the free market and restrain corporate management in the interests of corporate stakeholders.

See also David Millon, Frontiers of Legal Thought I: Theories of the Corporation, 1990 DUKE L.J. 201 (1990) (providing an overview of the two schools of thought regarding the corporation: conservative (shareholder wealth maximization) and progressive (stakeholder protection, social responsibility)). 
3. The manager has moral autonomy in the sense that his ethical duty is not solely to maximize economic benefits to the corporation's investors. $^{21}$

This section addresses whether those premises are satisfied with respect to middle and upper management in large American, publiclyheld corporations. ${ }^{22}$ We do not intend in this Part to completely rework

21. We use the term "investor" to avoid the need to address the debate whether managers owe their fiduciary duties primarily to the corporation, to its shareholders, or to a broader range of "stakeholders" because our views on that issue do not affect our analysis here. We will use the term "investor" to refer to all the beneficiaries of the fiduciary duty. The term is not meant to refer solely to a financial investor, but to any person who might be included in the set of persons who have a legal entitlement to a corporate benefit, including shareholders, creditors, employees, customers, vendors, and so on. (For the record, we believe that the better legal argument is that the duty is owed to the various stakeholders in a priority dependent on their reliance on the protections provided by that duty. A duty to such relying stakeholders is more consistent with Catholic Social Teaching.)

Although the issue is beyond the scope of this article, we should also include a word concerning investors' moral status. Because non-controlling investors in publicly-held corporations cannot be said to either cause or cooperate ex ante with most corporate actions or inactions, it is difficult to make a case that investors are morally responsible for corporate acts. This is especially so for the type of dilemma that is the focus of this essay. It is rare that investors become aware ahead of time of proposed actions that are morally objectionable, even for actions that are so material that they are subject to Board consideration. Further, with respect to day-to-day decisions on employment and product issues, it is virtually impossible for shareholders to obtain specific information, even in mandatory securities filings. Moreover, state law restrictions and SEC regulations limiting shareholder participation in shareholder meetings essentially preclude shareholders of public corporations from affecting corporate policy or actions relating to the corporation's ordinary business.

Therefore, the fundamental requisites for moral accountability of investors are simply not present unless the investor learns of the immoral corporate action and accepts the resulting financial returns. Accepting such returns could constitute formal or material cooperation, which would require the investor to divest her interest in the corporation. See GERMAIN GRISEZ, DIFFICULT MORAL QUESTIONS If 112 (1997). Grisez states that direct investment need not be wrong if one reasonably judges that the corporation's wrongful activities are unnecessary for the corporation's profitability and will contribute little to expected income. $1 d$. at 507. In that circumstance, the shareholder generally would have to sell the stock. In the case of the shareholder, an argument could be made that, if the investment is not otherwise objectionable and if the shareholder does not desire or intend the objectionable result, he could allocate the appropriate portion of his financial return to combating the continuance of the corporate action. $I d$.

22. We assume that managers have significant decision-making responsibility yet are neither substantial owners nor final decision-makers. Our analysis is not limited to directors or officers, nor do we separately consider the problems of managers in closely held corporations. In addressing those who are not "officially" directors or officers yet have significant roles in the corporation, we will presume that they have just as stringent a fiduciary duty of care as do executive officers. See generally 1969 MODEL BUS. CORP. ACT $\S \S 2,5,50$ (as amended through 1981); MODEL BUS. CORP. ACT $\S \S 1.40,8.42,8.50$ (1984) (incorporating changes through 1999); 8 Del. C. $\S \S 122,141,142$ (2004). This Article does not address issues of the fiduciary duty of loyalty-the duty to place the interest of the corporation and its stakeholders above the manager's own interests-because compliance with that duty should not create a Dilemma in our sense of the term. See, e.g., MODEL BUS. CORP. ACT. $\S \S 8.31,14.32$ (1984) (incorporating changes through 1999); 8 Del. C. $\S \S 141$, 144, 251, 271 (2004); Meinhard v. Salmon, 164 N.E. 545, 546 (N.Y. 1928) ("Joint adventurers, like copartners, owe to one another, while the enterprise continues, the duty of finest loyalty. Many 
the purposes of corporations and the nature and extent of the fiduciary duties of corporate managers; nevertheless, we must give these duties some consideration. ${ }^{23}$

\section{A. The Moral Status of the Corporation}

Are corporations independent moral agents who must take ethical considerations into account, or are they mere legal fictions such that only their owners and agents bear moral responsibility for corporate acts? Certainly legislatures and courts take a primarily structuralist view of corporations and hold them liable as separate legal persons. ${ }^{24}$ The issue of moral responsibility is more problematic, however, when the corporation is viewed as a network of dependent contractual relationships. $^{25}$ From that perspective, one could argue that each contracting party is morally responsible only for his own bargain, and that any resulting "corporate" immorality is simply a result of the failure of individual parties and should be addressed as such.

In the following section we argue that under both structuralist and contractarian theories, the corporation possesses a right to act based on ethical concerns as long as minimal-not maximal-economic fairness is maintained with respect to stakeholders.

forms of conduct permissible in a workday world for those acting at arm's length, are forbidden to those bound by fiduciary ties. A trustee is held to something stricter than the morals of the marketplace. Not honesty alone, but the punctilio of an honor the most sensitive, is then the standard of behavior.").

23. See, e.g., Woulter H.F.M. CortenraAd, The Corporate Paradox: EconomiC Realities of THE CorPorate Form (1999); Armen A. Alchian \& Harold Demsetz, Production, Information Costs, and Economic Organization, AM. ECON. REV. (1972); R. H. Coase, The Nature of the Firm, 4 ECONOMICA 386 (1937); ADAM SMITH, AN INQUIRY INTO THE NATURE AND CAUSES OF THE WEALTH OF NATIONS (New York: The Modem Library 1937) (Edwin Cannan ed., 1904); Michael C. Jensen \& William H. Meckling, Theory of the Firm: Managerial Behavior, Agency Control and Ownership Structure, 3 J. FIN. ECON. 305 (1976); EASTERBROOK \& FISCHEL, supra note 10; MILTON FrIEDMAN, CAPITALISM AND FREEDOM (1982).

24. There are situations in which courts vacillate between honoring a separate corporate existence and ignoring that existence when injustice would result. A primary circumstance for ignoring the separate existence is when the corporation fiction has been used as an instrument of fraud or for other morally questionable ends. In such an instance, the corporate veil will be pierced and the dominating shareholder held responsible. However, even in those cases, the corporation is not held free of responsibility. It is itself liable to the full extent of its resources. See Franklin A. Gevurtz, Piercing Piercing: An Attempt to Lift the Veil of Confusion Surrounding the Doctrine of Piercing the Corporate Veil, 76 OR. L. REV. 853 (1997). See also Robert B. Thompson, Piercing the Corporate Veil: An Empirical Study, 76 CORNELL L. REV. 1036, 1054-55 (1991).

25. Michael C. Jensen \& William H. Meckling, Theory of the Firm: Managerial Behavior, Agency Costs and Ownership Structure, 3 J. FIN. ECON. 305 (1976) (first to use term "nexus of contracts" to describe the contractual view of corporations). 


\section{The Corporation Viewed as a Separate Legal Person}

The legal "fiction" of corporation as "person" comports well with the widely accepted notion of "corporate responsibility," which confirms the popular acceptance of the moral responsibility of corporations as actors separate from management and shareholders. ${ }^{26}$ The case for independent moral accountability of publicly-held corporations is particularly strong when viewed as a matter of common sense and sound policy. ${ }^{27}$ That the law allows such a massing of resources under the guise of a single entity implicitly requires that the entity be subject to the same moral strictures as other participants in society; to allow such combinations of resources to operate free of moral censure except to the extent that a "controlling person" could be identified and held accountable would lead to over-investment in "sheltered" corporations as well as to a general weakening of moral authority and accountability. Even the libertarian Milton Friedman recognized this truth when he conceded that corporations must conform to commonly accepted ethical practices and "rules of the game" beyond mere profit maximization. ${ }^{28}$

Assuming, then, that corporations are moral actors in their own right, the question arises as to whether they have any moral obligation beyond the obligation to "do no (undue) harm" while maximizing economic returns for investors. The dominance of the Law and Economics movement and the victory of financial analysts as graders of corporate performance have led to a common perception that the sole purpose of a corporation is to make economic profit for its investors. ${ }^{29}$ If that view were accepted, one might argue that the corporation and its managers had decisional autonomy only to avoid harm not required by profit maximizing behavior.

Any investigation of the morality of managerial decisions must start then with a consensus on the purpose of the corporate entity that the

26. One line of thought holds "the corporate firm to be a real thing having an existence, like a spiritual being, apart from the separate existences of persons connected to it." William W. Bratton, Jr., The New Economic Theory of the Firm: Critical Perspectives from History, 41 STAN. L. REv. 1471, 1475 (1989).

27. The argument that corporations are morally independent and accountable is well summarized in Catholic Social Teaching. See note 118 infra and accompanying text.

28. "In a free economy there is one and only one social responsibility of business-to use its resources and engage in activities designed to increase its profits so long as it stays within the rules of the game, which is to say, engages in open and free competition, without deception or fraud." Milton Friedman, CAPITALISM AND Freedom 133 (Univ. of Chicago Press 1962) (1982).

29. Milton FRIEdMan, ESSAYS IN POSITIVE ECONOMICS 3-7, 15 (1953) (arguing that the neoclassical model does not suggest that managers should maximize profits so much as predict that they will do so). "[l]n competitive markets, a sustained commitment to any goal other than profitability will lead to bankruptcy unless collusion is permitted." RICHARD A. POSNER, ECONOMIC ANALYSIS OF LAW 310-11 (1977). 
manager represents. If a corporation is organized solely to profit the organizers, the argument that the manager's only duty is to make money is a strong one. Such a minimalist view of the corporate purpose, however, is simply inconsistent with the histories of most major American companies. A focus solely on financial returns cannot explain why the Wright brothers built airplanes ${ }^{30}$ or why Merck makes drugs. ${ }^{31}$ Instead, virtually all businesses originate out of the purpose to make a product or provide a service that will earn a financial reward for the investors and provide other material, psychological, and spiritual benefits to stakeholders. ${ }^{32}$ Thus, while investors of financial capital may be interested only in the financial aspects of a firm's business plan, owners/managers, employees, vendors and customers are generally interested to a substantial degree in the goods, both physical and otherwise, that the firm will produce.

To say that a corporation exists solely to make profits for investors cannot be supported even by examination of mature, successful corporations. If corporations existed solely to make profit, one would expect a glut of liquidations by American businesses involved in lower return industries in order that the invested resources could be efficiently reallocated to more profitable sectors. Even when businesses restructure by selling off under-performing subsidiaries or divisions, there are investors who stay with the under-performers for reasons that cannot be

30. The Wright brothers were dismayed that so many great minds had made little progress on human flight, and decided they had as good of a chance as anyone else in succeeding. WRIGHT Brothers, U.S. Department of the Interior National Park Service, Park Brochure, available at http://www.nps.gov/wrbr/indepth/index.htm (last updated Nov. 12, 2003).

31. "Our business is preserving and improving human life ... We expect profits, but only from work that satisfies customer needs and benefits humanity." МЕRCK.СОM, Mission Statement (2004), available at $\mathrm{http}: / / \mathrm{www}$. merck.com/about/mission.html.

32. "Whole Food Company (WFC) opened its doors in New Orleans in October 1974. Its mission was to be a grocery store featuring good, wholesome food; not a "health food" store filled with pills and potions. Sales doubled each year for the first four years. By 1978, the store (only 1100 square feet) was doing more than $\$ 1$ million per year. Success was fueled by a committed staff who were all stockholders in the company." WHOLE FOODS MARKET, Our History (2004), available at http://www.wholefoods.com/company/history.html.

Being committed to the social, economic and environmental health of the communities we serve is a key part of Target's heritage . . . Today, Target continues to work hard to enhance the communities we serve. We are actively engaged in programs that benefit families and young children through our donations of more than $\$ 2$ million dollars each week; we endeavor to design stores that complement and protect the environment in which we operate, even as we continue to grow; and we strive to adhere to the principles of integrity and strong corporate governance that have guided our business conduct and performance for decades.

TARGET, Corporate Responsibility Report (2004), available at http://www.corporate-ir.net/ireye/ ir_site.zhtml?ticker=tgt\&script=1 1935\&item_id='Corporate\%20Responsibility\%20v27e.html'. 
explained by profit-maximization. ${ }^{33}$ Further, if one were to assume that the investor's failure to divest was a result of bounded rationality, ${ }^{34}$ that bounded rationality itself would reflect a conscious recognition that corporations are not necessarily constituted to ensure that every last economic return is wrung out of the investment.

In short, financial return is just one of the goods for which a corporation is formed, and to conclude otherwise would be to discount virtually every mission statement of every Fortune 100 Company as fatuous. $^{35}$ Indeed, a fair observer could not even argue from such pronouncements that a corporation's primary purpose is to maximize profits. To the contrary, the common corporate promise regarding profit, if any, is to seek a fair, reasonable, or sustainable return-in other words, to create value for the shareholders within the context of the congeries of other interests. ${ }^{36}$

33. "A stock 'becomes more prized and valued precisely because we have invested something of ourselves in it,' says Brett N. Steenbarger, a clinical psychologist who applies behavioral science to the study of the stock market at SUNY Upstate Medical University in Syracuse, NY." Emory Thomas Jr., 8 Reasons You Don't Sell When You Should, MSN MONEY (2004) available at http://moneycentral.msn.com/content/Investing/Findhotstocks/P38815.asp.

34. By "bounded rationality," we refer to the related phenomena that (1) all relevant information is not available to market participants on a real time basis and (2) investors in making decisions are unable to absorb all potentially relevant information. See Melvin A. Eisenberg, The Limits of Cognition and the Limits of Contract, 47 STAN. L. REv. 211 (1995); R. Ted Cruz \& Jeffrey J. Hinck, Not My Brother's Keeper: The Inability of an Informed Minority to Correct for Imperfect Information, 47 HASTINGS L.J. 635 (1996).

35. "Ford Motor Company is committed to creating value for our shareholders over the long term through the delivery of excellent automotive products and services and to do so ethically and responsibly. These Principles will guide our decisions and actions globally. As a whole, they set the standards by which we judge ourselves and by which we hope to be judged by others." FORD Mотов Co., 2002 Corporate Citizenship Report, Our Principles (2003), at 9, available at $\mathrm{http} / / \mathrm{www}$.ford.com/en/company/about/corporateCitizenship/principlesProgressPerformance/genera 1/printing.htm. Coca-Cola promises that "[t] $]$ he Coca-Cola Company exists to benefit and refresh everyone it touches. The basic proposition of our business is simple, solid and timeless. When we bring refreshment, value, joy and fun to our stakeholders, then we successfully nurture and protect our brands .... That is the key to fulfilling our ultimate obligation to provide consistently attractive returns to the owners of our business." THE COCA-COLA CO., Our Company, Beliefs (2003), available at http://www2.coca-cola.com/ourcompany/ourpromise.html.

36. See, e.g., Ford's Corporate Citizen Report, supra note 35, at 64. "We will make our decisions with proper regard to the long-term financial security of the Company. We will achieve this by: striving to create value for our shareholders that is sustainable over the long term." See also, Bruce P. Frohnen, The One and the Many: Individual Rights, Corporate Rights and The Diversity of Groups, 107 W. VA. L. REV. 789, 835-845 (2005)(arguing that, up through the nineteenth century, business corporations were formed and sustained as communities pursuing substantive ends tied to the common good).

Of course, many business experts urge that this is just what is wrong with American business. By not making the final dollar the sole goal of corporate activity, managers have virtually stolen from shareholders. See Milton Friedman, The Social Responsibility is to Increase its Profits, N.Y. TIMES., Sept. 17, 1970 (Magazine). These experts likewise castigate major pension funds for failing to do their duties as shareholders and discipline errant managements. Daniel Fischel \& John $\mathbf{H}$. 
We can, therefore, legitimately speak of a publicly-owned corporation's purpose as the pursuit of a common good, i.e., a "basket" of interests, desires and outcomes that combine economic, psychological and sociological interests. By adopting this view, we do not deny the usefulness of the profit-maximization assumption for purposes of economic theory or business planning, ${ }^{37}$ nor do we deny that some investors may be pure homines economici who desire only financial return. To suggest that the predominant proportion of investors fall and ought to fall into that category, however, is to deny a salient characteristic of the American populace-a people coming from diverse religious, moral and cultural traditions, each of which espouses strong non-economic values such as family life, the environment, and personal freedom and integrity. To adopt a legal policy or normative construct that ignores the reality of non-economic norms which temper the desire to maximize economic gain would be to render a disservice to investors. Investors' actual "baskets" of wants would be ignored and an appreciation of humankind's interest in a society focused on human dignity and freedom, in addition to economic prosperity, would thereby be skewed. ${ }^{38}$

Langbein, ERISA's Fundamental Contradiction: The Exclusive Benefit Rule, 55 U. CH1. L. REV. 1105,1121 (1988) (because promised pension benefits are not directly tied to the investment performance of the fund, the risk of fund performance is borne mainly by the firm's stockholders). In our view, these experts are simply nostalgic for a time that never existed. The separation of management from public ownership is not the cause of the alleged inefficiency, but is the result of the fact that both as a result of bounded rationality and normative concerns, neither wealthy investors nor institutional investors are really driven by ultimate marginal returns. Instead, it is the sales force of Wall Street that creates experts to help it create transactions.

37. However, the strength of the principle can be doubted as a matter of public policy even from the viewpoint of economics because profit-maximization is central to economic theory only if the other basic assumptions of that theory are present. The fact that they are clearly not demonstrates that profit-maximization is hardly the basis on which to make moral determinations. Richard S. Markovits, Symposium on Second-Best Theory and Law \& Economics: An Introduction, 73 CHI.KENT. L. REV . 3, 3 (1998) ("According to The General Theory of Second Best, if one or more members of a set of optimal conditions cannot be fulfilled, there is no general reason to believe that fulfilling (or more closely approximating) more of the remaining conditions will bring you closer to the optimum than fulfilling fewer of the remaining conditions."). R. H. Coase has lamented that economists have become preoccupied with the "logic of choice" and have divorced theory from its subject matter:

The consumer is not a human being but a consistent set of preferences. The firm to an economist, as Slater has said, "is effectively defined as a cost curve and a demand curve, and the theory is simply the logic of optimal pricing and input combination." Exchange takes place without any specification of its institutional setting. We have consumers without humanity, firms without organization, and even exchange without markets.

R. H. Coase, The Firm, the Market, and the Law 3, (Univ. of Chicago Press 1988).

38. As J.M. Balkin has noted:

We may ask whether market behavior is not itself simply a special case of human behavior-whether it too, is only one of a number of different forms of human choice, which in turn depend upon many different forms of human valuation and motivation. 


\section{The Corporation Viewed as a Nexus of Contracts}

The conclusion that a corporation does not exist solely for the purpose of wealth maximization follows even if the corporation is understood not as a separate legal person but as a web of contractual relationships. ${ }^{39}$ In its best light, a contractarian theory attempting to justify profit-maximization would have to argue along the following lines. First, corporations must maximize profits because profitmaximization results in the fairest allocation of risks among investors ${ }^{40}$ by rewarding the common shareholders-generally assumed to be the holders of residual risk - for the risks of being last at the firm's economic trough. ${ }^{41}$ Second, because the corporation on this theory would be nothing more than a conglomeration of individually negotiated contracts ultimately made for the benefit of common shareholders, the corporate manager usurps authority and interferes with individual freedom when she rewrites those contracts by changing the assumptions and choices

\footnotetext{
Human values and goals may take wealth maximization into account, but they may not be exclusively or even primarily concerned with it. Human action and human decision may rest only in part on the type of reasoning acceptable to Landes and Posner's reductive vision. Ironically, then, the greatest problem with wealth maximization as a theory of human practical reason may be that it is insufficiently rich.
}

J.M. Balkin, Too Good to Be True: The Positive Economic Theory of Law, 87 ColuM. L. REV. 1447, 1475-76 (1987) (reviewing William M. LANDes \& Richard A. POSNER, THE ECONOMIC StRUCTURE OF TORT LAW 1 (1987)). See also Edward C. Lyons, Balancing Acts: Intending Good and Foreseeing Harm-The Principle of Double Effect in the Law of Negligence, 3 GEO. J. L. \& PUB. POL'Y. (forthcoming 2005) (Part 2.A.3, on file with authors) (rejecting rationality of economic efficiency model of tort law).

39. "Contractarians view the corporation as a set of private contractual relationships among providers of capital and services." Henry N. Butler \& Larry E. Ribstein, Opting Out of Fiduciary Duties: A Response to the Anti-Contractarians, 65 WASH. L. REv. 1, 3 (1990).

40. D. Gordon Smith, The Shareholder Primacy Norm, 23 J. CORP. L. 277, 278 (1998) ("Corporate directors have a fiduciary duty to make decisions that are in the best interests of the shareholders. This aspect of fiduciary duty is often called the shareholder primacy norm.").

41. Frank H. Easterbrook \& Daniel R. Fischel, Contractual Freedom in Corporate Law: Articles \& Comments; The Corporate Contract, 89 Colum. L. REv. 1416, 1446-47 (1989):

For most firms the expectation is the residual riskbearers [the stockholders] have contracted for a promise to maximize long-run profits for the firm, which in turn maximizes the value of their stock. Other participants contract for fixed payoutsmonthly interest, salaries, pensions, severance payments, and the like. This allocation of rights among the holders of fixed and variable claims serves an economic function. Riskbearers get a residual claim to profit; those who do not bear risk on the margin get fixed terms of trade.

See also Thomas A. Smith, The Efficient Norm for Corporate Law: A Neotraditional Interpretation of Fiduciary Duty, $98 \mathrm{MiCH}$. L. REV. 214, 214-16 (1999) (acknowledging the predominant view that the corporate fiduciary duty requires firm managers to "maximize shareholder value," but "[n]evertheless, the economic approach to corporate law does not foreordain the maximization of shareholder value as the primary norm of corporate law."). 
implicit in them. ${ }^{42}$ In such a case, allowing a manager to refuse to maximize profits, whether for moral or other reasons, would itself be immoral because it would constitute an unauthorized reallocation of investors' implicitly bargained-for risk allocations. ${ }^{43}$

A number of responses can be made to this view of corporate existence as founded upon shareholder primacy. The first and most fundamental is that this approach assumes that one of the corporation's bargained-for duties is to maximize investor returns. This assumption, however, cannot be sustained with publicly-held companies, virtually all of which have publicly represented for decades that they are not profitmaximizing in any strict sense of the term. ${ }^{44}$ Any investor who assumes that the corporation in which he or she invests will wring every last dollar of return out of that investment has not in fact been paying attention to the "contract." 45

Even in today's world where earnings projections greatly affect investment decisions, those projections say nothing about the role of profit-maximization within the corporate enterprise. When a General Electric, ${ }^{46}$ a Berkshire Hathaway, ${ }^{47}$ or a Microsoft ${ }^{48}$ projects that it will

42. See Friedman, supra note 29; Daniel R. Fischel, The Corporate Governance Movement, 35 VAND. L. REV. 1259 (1982).

43. "A corporation ... is nothing more than a legal fiction that serves as a nexus for a mass of contracts which various individuals have voluntarily entered into for their mutual benefit . . $[\mathrm{M}]$ anagers should act to maximize wealth of investors pursuant to the terms of the contract of their agency relationship." Fischel, supra note 42, at 1273.

44. See GE, AT\&T, PRG, FORD and SHELL, supra note 9; WHOLEFOODS and TARGET supra note 32; FORD MOTOR CO. and COCA-COLA, supra note 35.

45. Even Easterbrook and Fischel do not object to a refusal to maximize profits as long as it is disclosed:

If the venture at its formation is designed in the ordinary fashion-employees and debt investors holding rights to fixed payoffs and equity investors holding a residual claim to profits, which the other participants promise to maximize-that is a binding promise. If the firm suddenly acquires a newspaper and declares that it is no longer interested in profit, the equity investors have a legitimate complaint. It is a complaint for breach of contract, not for derogation from some ethereal ideal of corporate governance.

Easterbrook \& Fischel, supra note 41, at 1446.

46. GE, Our Company, Values (2004), available at http://www.ge.com/en/company/ companyinfo/at_a_glance/ge_values.htm:

In the end, our success is measured not only by our ability to think big, dazzling thoughts, but by our commitment to sweat the small stuff that brings ideas to life. It's a waythinking and doing - that has been at the heart of GE for years. The worth of this framework is how we translate it into our own personal work ethic and then extend it to our teams, businesses, cultures and different regions of the world. It's permission to cast aside any approach that seems dated-to imagine, solve, build and lead a better way of doing things.

Id.

47. "The Company is proud of the values with which it conducts business. It has and will continue to uphold the highest levels of business ethics and personal integrity in all types of 
earn $x$ dollars per share next quarter, it knows that those earnings will come from doing business consistent with its public statements of good corporate citizenship. Assessing the precise residual risk that the bearer can assert becomes an important question. Since no investor can predict which company decisions are motivated by maximum profit and which by ethical obligation, the investor is really investing in lines of business as specifically directed by key executives such as the (now-retired) Jack Welch, Warren Buffet, or Bill Gates-along with all their personal business and moral predilections. ${ }^{49}$ In public companies with less stellar or dominant leaders, the investor is really buying an interest in management that asserts it will attempt to maximize the value of the investment within the parameters of that bureaucracy's view of good corporate citizenship. Any CEO who promised more would be viewed as a maverick.

One way to evaluate these competing claims concerning the actual terms of the shareholder's contract is to look at the admittedly thin case law on shareholder primacy. The most extreme case for shareholder primacy is Dodge v. Ford Motor Co ${ }^{50}$ In Dodge, the appellate court granted minority shareholders' demands for higher dividends in large part because Henry Ford testified that the shareholders were making enough money and that he planned to devote the corporation's resources to other goals if and when certain profit targets were met. ${ }^{51}$

Dodge, however, does not support a strong version of the duty to maximize profits for the shareholder. First, the court stated only that the business of a corporation is carried on "primarily for the profit of the shareholders," 52 and thus, there is no absolute prohibition on other goals that may impact shareholder profit. Second, the court refused to interfere with a proposed expansion of Ford's business, recognizing that courts are not experts in business and are not in a position to second-guess management's projections. ${ }^{53}$ Thus, shareholder primacy is not absolute

transactions and interactions." BERKSHIRE HATHAWAY, Corporate Governance, Code of Business Conduct and Ethics (2004), available at http://www.berkshirehathaway.com/govern/ethics.pdf.

48. "We have worked hard to make Microsoft a values-driven company that maintains the highest standards of professional conduct, meets or exceeds the ethical and legal expectations of countries where we do business, and seeks to enable people throughout the world to realize their full potential." Microsoft 2004 Global Corporate Citizenship Report, Executive Welcome, available at http://www.microsoft.com/mscorp/citizenship/report/default.mspx.

49. Any such investment, of course, unrealistically ignores the role of the huge corporate bureaucracy in instigating or derailing executive pronouncements.

50. 170 N.W. 668 (Mich. 1919).

51. Id. at 684 .

52. Id. (emphasis added).

53. Id. at 684-685. 
and is greatly weakened when management is addressing the future impact of corporate decisions.

The only light that Dodge sheds on the current inquiry, then, is that the shareholder primacy right to maximized profit has always been a myth. Assume, for example, that Ford Motor Company publicly announces that henceforth each corporate manager will be instructed that he may choose to forego short-term and reduce long-term profits if seeking such profits would be (1) morally wrong or (2) preventive of an imperative moral good, as he determines in accordance with his informed personal conscience based on mandatory or prudential moral reasoning. Could Ford's shareholders complain in a court of law? ? $^{54}$

One would have to inquire into the precise nature of the change in the "rules." If Ford, like most corporations, had made typical pronouncements regarding limited profit-maximization and corporate responsibility, ${ }^{55}$ the investor would have a difficult time showing reliance that could lead to a specific measure of damages. ${ }^{56}$ In other words, although the corporation might have represented that it would in some sense attempt to maximize profits, there would always be sufficient notice of potentially deviant behavior and a lack of definiteness. In such

54. According to Easterbrook \& Fischel, persons who assumed residual risk (i.e., purchased common stock) after that declaration was disseminated in the market could have no complaint about a change in the corporate policies and the resulting change in risk assessment rules:

If the New York Times is formed to publish a newspaper first and make a profit second, no one should be allowed to object. Those who came in at the beginning actually consented, and those who came in later bought stock at a price reflecting the corporation's tempered commitment to a profit objective. If a corporation is started with a promise to pay half of the profits to the employees rather than the equity investors, that too is simply a term of the contract. It will be an experiment. We might not expect the experiment to succeed, but such expectations by strangers to the bargain are no objection.

Easterbrook \& Fischel, supra note 41, at 1446.

55. As Ford has in fact done. See supra notes 9,35 , and 36.

56. Phrasing the issue in terms of a cause of action for damages, which is an economic substitute for the lost returns, is not a bait and switch from the moral perspective that is the basis for this essay. The argument of the investor is that she, as a purely economic investor, has been economically harmed by the shift away from profit-maximization. Dodge v. Ford Motor Co., 170 N.W. 668 (Mich. 1919). Since her argument is limited to economics, it is not unreasonable to evaluate it solely on those terms. If her argument had been that the corporation had shifted from one non-economic purpose (building affordable housing) to another (marketing cigarettes), the analysis would be somewhat the same, but would necessarily entail more non-economic normative analysis. For example, it would still be fair to inquire as to the assurances, if any, that the corporation had made regarding the original corporate purpose. If the investor could demonstrate reliance on the noneconomic purpose, as discussed infra note 70 , she might be entitled to a remedy that would allow her to recover for whatever reliance interest the market would not compensate when she sold her stock. Notice, however, that the ability to sell her stock to avoid investment in a business with which she does not agree redresses her (primary) non-economic injury, so that her only remaining damage is the economic damage that is addressed by the discussion in the text. 
circumstances, no court should find an enforceable promise to maximize profits, in the sense used by economists. ${ }^{57}$

Even if there were an explicit or implicit contract for profitmaximization, the shareholder, as a residual risk holder, still might not have a complaint. The shareholder's interests as residual risk holder consist of the right to vote shares on matters prescribed by statute or agreement and to receive residual cash flow in the form of dividends and liquidation payments; $;^{58}$ a change in purpose or strategy does not affect the voting right per se. Thus, our purely economic investor would have a complaint, if at all, only if the stock price had fallen after the announcement. ${ }^{59}$

The complaint could take one of three forms. First, the investor could claim that the corporation breached a contract or committed a fraud based on an insincere assurance that the corporation would always maximize profits. However, as argued above, any such promise would likely be qualified enough that any contractual cause of action based on it would prove unsuccessful.

Second, the investor could argue that the new policy was ultra vires, that is, beyond the power of the corporation. While such an argument might have been persuasive in the days of yore, ${ }^{60}$ modern

57. Indeed, the Efficient Capital Markets Hypothesis accepted by most law and economics adherents holds that disclosures regarding corporate philosophy and results are subsumed into share prices fairly quickly. For a particularly facile use of the ECMH, see Wielgos v. Commonwealth Edison Co., 892 F.2d 509 (7th Cir. 1989). Thus, any previous muddy statements on corporate responsibility that investors would reasonably interpret as hints of a risk of non-profit-maximization behavior would have already caused a downward adjustment in the stock price. If those statements occurred before the investor bought the stock, there would clearly be no damage.

58. That residual cash flow can, of course, be anticipated by selling the stock for a price equal to the investor's judgment of those future flows discounted to present value.

59. It might be worth noting that, if the ECMH is valid, investors buying after the disclosure would have paid a price that reflected discounts for both the risk of diminished future cash flows from non-profit-maximizing behavior and the risk of damage awards to investors who were shareholders at the time of the announcement. Simply stating the rule demonstrates the problem any investor would face in pursing a damage action. One might also ask whether a corporation (and ultimately its stakeholders) should be sanctioned with damages that reflect an unreasonable perception of the risk of the damage award. In other words, one could argue that the corporation should not have to pay damages for a drop in the post-disclosure sales price that was greater than the drop in valuation that the plaintiff could show would reasonably result from post-disclosure nonprofit-maximization.

60. See Franklin A. GevurtZ, Corporation LAw $\S 1.1$ (West 2000). See also Jacksonville, M., P. Ry. \& Nav. v. Hooper, 160 U.S. 514, 524-25 (1896); Thomas v. Railroad Co., 101 U.S. 71, 83 (1879) (holding that an ultra vires act is void ab initio and cannot be ratified by the shareholders). See also Brinson Ry. Co. v. Exchange Bank, 16 Ga. App. 425, 425 (1915) ("The president of a railway company incorporated under the general laws of Georgia as a common carrier has no power, either with or without the consent of its board of directors, to donate funds belonging to the corporation, or to execute in the corporate name a note to be discounted in behalf of or to raise funds as a recognized donation for the erection of a public school, or for the purpose of building up or 
legislatures and courts have seen fit to limit the ultra vires doctrine to a limited class of purely gratuitous transfers known as corporate waste. ${ }^{61}$ Here, the claimed ultra vires act, however, would be the corporation's avoidance of a perceived moral wrong, a limited circumstance traditionally viewed sympathetically by courts. ${ }^{62}$ Because the corporation is still oriented primarily to economic benefit within its accepted noneconomic parameters, the argument that no ultra vires action should lie is a persuasive one. ${ }^{63}$

Finally, it should also be clear that even if the manager had a duty to maximize profits, the business judgment rule would protect her from liability to investors for a breach of the duty in the absence of fraud, illegality or bad faith. ${ }^{64}$ In other words, mere imprudence (even stupidity) would not be sufficient to allow an investor to overcome the good faith

promoting the town in which the school is situated, even though the school or town be located on the line of the company's railway and its transportation business might thereby be increased."); McCrory v. Chambers, 48 Ill. App. 445, 453 (1892) ("The incidental powers are such as are necessary to the efficient exercise of the express powers. A donation of the funds of a bank is prima facie unauthorized. Such power is not expressly given, nor is it apparent, in the absence of proof of special circumstances, that it is necessary to the proper and successful exercise of any express power.").

61. Franklin A. Gevurtz, Corporation laW $\S 3.1 .4$ (West 2000). See also Wolf v. Lutheran Mut. Life Ins. Corp., 18 N.W.2d 804, 809 (Iowa 1945) ("courts [will not] control or interfere in the internal management or policy of a corporation except in cases of fraud, bad faith, breach of trust, gross mismanagement, or ultra vires acts"). See also Coming Glass Works v. Lucas, 37 F.2d 798, 801 (D.C. Cir. 1929) (holding that it was not unlawful for Corning Glass to contribute to a hospital used by its employees: "These employees and their dependents must have constituted two-thirds of the population of the city. If the moral welfare of such a large number of employees and their dependents would have justified a contribution for the erection or support of a church, we think it equally plain that a contribution having for its direct object the physical well-being of employees and their dependents would likewise be justified."); Whetstone v. Ottawa Univ., 13 Kan. 320,340 (1874) ("If the direct and proximate tendency of the donation is the building up of the town, and the enhanced value of the remaining property of the corporation, the donation is not ultra vires.").

62. Note that even here the corporation could defend the new policy on the ground that it is long-term profit-maximizing at a macro level since neither managers, employees, other affected stakeholders nor the public will want to be affiliated with a company that condones moral wrongs on the basis of profitability. For an excellent argument in this regard, see Melvin A. Eisenberg, Corporate Conduct That Does Not Maximize Shareholder Gain: Legal Conduct, Ethical Conduct, the Penumbra Effect, Reciprocity, the Prisoner's Dilemma, Sheep's Clothing, Social Conduct and Disclosure, 28 STETSON L. REV. 1 (1989).

63. Moreover, any remedy should be limited to damages, since the ECMH posits a drop in market price that reflects the best judgment as to future harm. Granting an injunction would frustrate pursuit of the broader corporate common good without additional benefit to the dissenting investor. See In re Sahlen \& Assoc., Sec. Litig., 773 F.Supp. 342, 354 (S.D. Fla. 1991) ("[T]he efficient capital market hypothesis which assumes that material information about a company is immediately reflected in the price of the stock. Because the market is interposed between the buyer and seller, there is no need to prove subjective reliance.").

64. See Schlensky v. Wrigley, 237 N.E.2d 776 (III. App. Ct. 1968). 
judgment of the manager. The investor would have to show impudence to overcome the manager's judgment. ${ }^{65}$

In short, the weakness of such an approach is the weakness of the contractarian perspective: The "contracts" in question are generally not "contracts" in the sense of being individually negotiated, bargained-for and assented to arrangements. Instead, they are in large part theoretical bargains inferred post hoc for the sake of abstract analysis of shareholder versus corporate rights and do not generally reflect conscious decisions of the parties clearly defining the scope of corporation conduct vis-à-vis the community at large. ${ }^{66}$ Indeed, a fundamental benefit of contractarian analysis is that it provides insights into risk allocations that the parties could have made had they not been hampered by bounded rationality. ${ }^{67}$ Because we cannot expect specific consideration of moral decisions to occur in such theoretical constructs, the contractarian perspective really has little to offer in resolving the moral dilemmas of managers other than explaining those dilemmas away by begging the question of what terms are included in the "contract."

\section{The Perspective of the ALI Principles of Corporate Governance}

The Principles of Corporate Governance adopted by the American Law Institute strongly support our arguments against a "profit maximizing" view of shareholder primacy by recognizing a distinct place for ethical decision making, even at the expense of corporate profit. ${ }^{68}$ The ALI corporate guidelines indicate that profit maximization need not provide the over-arching principle limiting corporate or managerial conduct. Section 2.01(a) of the Principles provides that a corporation

65. The question as posed does not raise any issue about the manager's good faith in becoming informed about the relevant facts or the basis for the decision. $C f$. Smith v. Van Gorkum, 488 A.2d 858 (Del. 1985). Nor would there appear to be any issue of illegality, fraud, or conflict of interest (breach of the duty of loyalty).

66. "The neoclassicists also make assumptions about the contracting process. They assume effective competition among the contracting parties. They apply the principle of natural selection to successive generations of the contracts. This follows from their assumption that rational economic actors, consciously or not, solve problems in the process of maximizing wealth." William W. Bratton, Jr., The "Nexus of Contracts" Corporation: A Critical Appraisal, 74 CORNELL L. REV. 407, 417 (1989).

67. Id.

Its actors are rational, economic actors driven by their divergent self-interests, and seeking to maximize values for themselves. They resourcefully conceptualize and predict future courses of action effectively. The neoclassical theorists reconstruct the firm as the product of their contracting behavior: Their contracts are equilibrium market contractsinstantaneous exchanges between maximizing parties. The parties make complete choices, dealing with unknown factors in the exchange price.

Id.

68. PRINCIPLES OF CORPORATE GovernanCE $\S 2.01$ (American Law Institute 1994). 
"should have as its objective the conduct of business activities with a view to enhancing corporate profit and shareholder gain." 2.01(b) even further weakens the notion of shareholder primacy, providing:

Even if corporate profit and shareholder gain are not thereby enhanced, the corporation, in the conduct of its business:

1. Is obliged, to the same extent as a natural person, to act within the boundaries set by law;

2. May take into account ethical considerations that are reasonably regarded as appropriate to the responsible conduct of business; and

3. May devote a reasonable amount of resources to public welfare, humanitarian, educational, and philanthropic purposes. ${ }^{70}$

The ALI's Comments to $\S 2.01$ are also instructive. Comment (f) on the "economic objective" states:

In very general terms, Subsection (a) may be thought of as a broad injunction to enhance economic returns, while Subsection (b) makes clear that certain kinds of conduct must or may be pursued whether or not they enhance such returns (that is, even if the conduct either yields no economic return or entails a net economic loss). ${ }^{71}$

Comment (h) on "ethical considerations" is even more explicit:

[O]bservation suggests that corporate decisions are not infrequently made on the basis of ethical considerations even when doing so would not enhance corporate profit or shareholder gain. Such behavior is not only appropriate, but desirable. Corporate officials are not less morally obliged than any other citizens to take ethical considerations into account and it would be unwise social policy to preclude them from doing so.

This does not mean that corporate officials can properly take into account any ethical consideration, no matter how idiosyncratic. Because such officials are dealing with other people's money, they will act properly in taking ethical principles into account only where those considerations are reasonably regarded as appropriate to the responsible conduct of business. In this connection, however, it should be recognized that new principles may emerge over time. A corporate

69. Id. at $\S 2.01$ (a) (emphasis added to denote the non-mandatory and non-specific nature of the provision).

70. Id. at $\& 2.01$ (b) (emphasis added).

71. Id. at $\$ 2.01 \mathrm{cmt}$. $\mathrm{f}$ (emphasis added). 
official, therefore, should be permitted to take into account emerging ethical principles, reasonably regarded as appropriate to the responsible conduct of business, that have significant support although less-than universal acceptance. ${ }^{72}$

The ALI's formulation, based as it is on extensive consideration by leading corporate scholars and practitioners, should preclude outright rejection of this article's premise. Even if one concluded that the hypothetical new Ford policy, proposed above in the discussion of Dodge v. Ford, was improper as applied in a specific circumstance, the policy as a whole should still be permitted. Further, given the clear public interest in corporate social responsibility as reflected in the ALI Principles, a corporate fiduciary arguably would not act imprudently and impudently in refusing to cause the corporation to take what in good faith is perceived as an immoral action.

On the other hand, corporations need not be totally free to take the moral high road. A finding that the specific action was ultra vires would not be objectionable if (1) the investor demonstrated a reliance interest on profit-maximizing rhetoric and behavior and (2) actual damages were limited to the causally related drop in stock price. ${ }^{73}$ In other words, if the corporation promulgates a clear profit-maximizing business plan and the directors or managers later change course, the corporation and its non-

72. Id. at $\S 2.01 \mathrm{cmt}$. h (emphasis added). AMERICAN LAW INSTITUTE, PRINCIPLes OF CORPORATE GOVERNANCE: ANALYSIS AND RECOMMENDATIONS 71 (American Law Institute Publishers 1994) ("Modem cases have, in effect, dropped this direct-benefit test, and permitted the utilization of corporate resources for public welfare, humanitarian, educational, or philanthropic purposes without requiring a showing that a direct benefit is likely ... Generally speaking however . . the modern cases have invoked a limit of reasonableness on the utilization of corporate resources for public welfare, humanitarian, educational or philanthropic purposes."). See also Kelly v. Bell, 266 A.2d 878, 879 (Del. 1970) (finding that it was a sound business decision on the part of the corporation to continue to pay the state taxes on existing machinery after the tax was eliminated); Union Pacific R.R. v. Trustees, Inc., 329 P.2d 398, 402 (Utah 1958) (holding that corporations can make "contributions of reasonable amounts to selected charitable, scientific, religious or educational institutions, if they appear reasonably designed to assure a present or foreseeable future benefit to the corporation"); Sorensen v. Chicago, B. \& Q. R. Co., 199 N.W. 534, 537 (Neb. 1924) ("We see no reason why a railroad corporation may not, to a reasonable extent, donate funds or services to aid in good works.").

73. Even in this instance, it would seem preferable as a conceptual matter for the ultra vires doctrine to be consistent with fiduciary doctrine applicable to directors. As argued supra at note 62, a shareholder suit against a director for breach of the fiduciary duty of due care arising from a refusal to sell a profitable but morally objectionable product, such as anthrax, would not succeed. A corporation should not be held liable for failing to pursue an action that its directors are not obliged to cause it to pursue. See Schlensky v. Wrigley, 237 N.E.2d 776 (Ill. App. Ct. 1968) (holding that Wrigley did not have to install lights and schedule night games for the Chicago Cubs, even though it might be economically beneficial, if it believed that night games might cause the neighborhood to deteriorate). 
objecting shareholders should, as a matter of commutative justice, bear the cost of changing the rules. ${ }^{74}$

\section{B. The Moral Status of the Corporation's Managers}

\section{Do Managers Cede Moral Responsibility?}

Even if a corporation has moral responsibility and autonomy, it does not necessarily follow that a corporate manager is morally responsible for her role in the actions of the corporation. Indeed, there seems to be a common perception that a manager cedes moral responsibility when she accepts a position and assumes the fiduciary obligation of care to the corporation and its investors. In other words, the assumption is that managers check their consciences at the door when they become corporate employees.

The reasoning behind such an assumption is far from clear. Even under a contractarian view, there is no basis for concluding that investors would demand or that managers would be willing to oversee an enterprise operating without morals. If traditional workplace wisdom and employment contract "morals clauses" regarding employee honesty, work ethic, and fair dealing are to be taken at face value, then, by extension of that same reasoning, "de-moralizing" the employees would potentially have a deleterious effect on long-term profitability and would be inconsistent with shareholder-corporate agreements. No business would thrive if, for example, its employees felt free to cheat and defraud vendors, customers and each other. Certainly, we would not expect the majority of investors and managers, even if they were willing to incur the transaction costs necessary to make specific contracts with each other, to agree to such conduct.

Yet the reality evidenced by the statements of the Stride Rite chairman, cited at the start of this article, demonstrates that even sophisticated managers mistakenly believe that they have abdicated their moral autonomy in light of their duty to investors. ${ }^{75}$ That view might make sense in a world where the investor was a monolithic force making

74. Black's Law dictionary defines commutative justice as "Justice concerned with the relations between persons and esp. with fairness in the exchange of goods and the fulfillment of contractual obligations." BLACK'S LAW DICTIONARY 881 (8th ed. 2004).

75. One could read the quotation as simply evidencing that the Stride Rite management did not believe it had the freedom to be "charitable" and give investor money away to those adversely affected by the plant closing who might be deserving but not wronged in any moral sense. Such an interpretation would be consistent with the oft-held notion that justice is an obligation, but charity is an option and a matter of free will. Because we believe that the justice-charity distinction as phrased is not consistent with Catholic Social Teaching, we will not pursue that weaker formulation of the problem. 
its own moral judgments and only requiring ministerial role players to carry out those judgments, though history has, of course, condemned this way of justifying the abdication of personal moral responsibility, as the standard but useful allusion to Nazi Germany demonstrates. The moral responsibility of those occupying representative roles has been thoroughly addressed elsewhere, ${ }^{76}$ and discussion of the arguments for it is beyond our scope. The better-reasoned view is that an employee, agent, attorney, or anyone acting on another's behalf is generally held morally accountable for participating in or cooperating with moral wrongs of the principal unless those actions are beyond the representative's control and are effected without his cooperation. ${ }^{77}$

Opponents of independent manager morality might argue, however, that the moral imperative of a manager should be limited only by universally accepted notions of ethics, such as following Friedman's "rules of the game": Namely, that an employee cannot lie, cheat, or steal on behalf of the corporation any more than on his own time, but still he has no right or duty to thwart profit-maximizing behavior on the basis of particularized moral beliefs. Such a strictly limited role for manager morality, however, is insufficient and inherently unworkable.

There are few moral principles more fundamental to American notions of fair play than the Golden Rule: "Do unto others as you would have them do unto you." Application of this rule requires more nuanced reasoning and consideration than a simple "Don't steal, cheat or lie," however; as discussed in more detail in Part IV below, application of the Golden Rule to typical business situations may readily lead to behavioral decisions impinging on long-term profit-maximization. Many managers in the 1950s and 1960s, for example, would not have considered internalizing the cost of water or air pollution because to do so would have lowered profits. If, however, they had followed the Golden Rule in their relations with downstream and downwind neighbors, they would have reduced pollution or compensated those neighbors despite the fact that compensation was not legally required. ${ }^{78}$

76. Arthur Applebaum offers a particularly persuasive analysis of the inadequacy of the notion that role players are not morally responsible. ARTHUR ISAK APPLEBAUM, ETHICS FOR ADVERSARIES (1999).

77. Id.

78. This argument also ignores the reality of human nature and the effects of bounded rationality. In any publicly-held corporation, projections regarding future profitability are only rough estimates based on virtually unlimited explicit and implicit assumptions. One necessary assumption is that all affected persons will act "normally." Since normal behavior includes the exercise of moral autonomy, any projection regarding long-term profitability in a world of hypothetical amoral actors would be inherently unreliable. 
The concept that managers have no right to their own moral authority beyond universal prohibitions against theft or fraud is also inconsistent with existing corporate law. The fiduciary duty of care requires a manager to conduct corporate affairs as a reasonably prudent person would in like circumstances, or, as framed by the Revised Model Business Corporation Act, as she reasonably believes to be in the corporation's best interests. ${ }^{79}$ It does not seem unreasonable to assume that a manager seeking to fulfill that duty would undertake the following in a consistent manner:

- Obey applicable laws;

- Play by the rules of business ethics;

- Honor contractual obligations through performance or compensation (expectation damages);

- Carry on the core business of the corporation so as to optimize the discounted present value of future cash flows to residual risk holders within the risk parameters accepted by the original investors as amended by later disclosures; and

- Cause the corporation to be a good citizen as if it were an individual.

A manager who complies with this list would be satisfying due care, though it does not follow from this that a manager who responds to moral issues would in some way be acting beyond or violating that duty. In fact, the ALI Principles provide that a corporation must be free to take into account whatever ethical considerations are "reasonably regarded as appropriate." ${ }^{80}$ Because the corporation cannot act except through its agents, the determination of precisely which ethical considerations are appropriate and when they should be taken into account falls to the managers, subject to shareholder voting control.

\section{Whose Ethics Should Apply?}

The issue, then, is whose ethics provide the yardstick. In the context of the publicly-held corporation, investors' ethics cannot be decisive since, as a practical matter, they are unknowable and, in our "multicultural society," are generally presumed to be divergent in many respects. Under general principles of corporate governance, it would

79. MODEL BUS. CORP. ACT $\S 8.30$ (a) (2000).

80. PRINCIPLES OF CORPORATE GOVERNANCE $\S 2.01 \mathrm{cmt}$. h (American Law Institute 1994) (emphasis added). American Law INSTITUTE, Principles of CoRPorate Governance: ANalysis and ReCOMmendations 71 (American Law Institute Publishers 1994). 
naturally fall to the board of directors to select the normative principles that the corporate managers would employ in the course of the corporation's business. But absent such direction from the board, managers should have discretion to exercise the corporation's freedom to temper profit-maximization with ethical considerations. Whether the manager, in the absence of board direction, may follow her own moral compass is an oft-asked question. The ALI is clear that the ethical considerations need not be universal, provided they are not "idiosyncratic" and are "reasonably related to the conduct of business.",81

While one could argue that American multiculturalism means that corporations can employ only the lowest common denominator of moral principles, the ALI Principles reject that approach in favor of a general reasonability test. Thus, managers-absent prior corporate or shareholder voted limitations-should be free to act according to their own sincerely held moral views if the permission to take moral considerations into account is to be meaningful. Any other conclusion would suggest that managers are required to employ moral considerations that they themselves believe are invalid or inadequate as applied to the situation at hand, which would require them to forego the very judgment they were retained to exercise.

\section{Are Managers Free to Do Good?}

That corporations may be managed in compliance with the minimalist ethical principle "do no harm," as explored in the last section, does not appear to be seriously disputed, at least to the extent that the corporation is following the law, avoiding tort liability, and otherwise playing by the "rules of the game" of good business. The notion that managers are also free to forego profit-maximization in order to "do good" (that is, to act solely to better the position of a non-investor) because of moral considerations is obviously more controversial. ${ }^{82}$ In this

81. Id.

82. See Milton Friedman, The Social Responsibility of Business is to Increase its Profits, N.Y. TIMES, Sept. 13, 1970 (Magazine):

[T] he corporate executive is also a person in his own right. As a person, he may have many other responsibilities that he recognizes or assumes voluntarily-to his family, his conscience, his feelings of charity, his church, his clubs, his city, his country. He may feel impelled by these responsibilities to give part of his income to causes he regards as worthy, to refuse to work for particular corporations, even to leave his job, for example, to join his country's armed forces ... But in these respects he is acting as a principal, not an agent; he is spending his own money or time or energy, not the money of his employers or the time or energy he has contracted to devote to their purposes. If these are "social responsibilities," they are the social responsibilities of individuals, not of business. 
section, we analyze whether a right to do good exists under two potentially applicable ethical standards using the following hypothetical case: ${ }^{83}$

A pharmaceutical company is considering whether to modify one of its drugs to combat a fatal disease in the Third World and save 50,000 lives a year. The modification would reduce short-term profits because Third World consumers could not pay a price sufficient to cover the development, testing, production and distribution costs, and Third World governments are unwilling (for political reasons) to purchase the drugs or subsidize their purchase. Although in other similar cases the responsible managers might rationalize a long term profitability rationale stemming from potential future concessions in the affected countries with respect to other products of the corporation and from favorable public relations and good will in the U.S. and worldwide, corporate managers cannot in good faith conclude in this case that actual corporate profitability would be enhanced. The corporation already has double digit profit margin monopoly power in its patented drug markets and is subject to intense price competition in its generic products. The corporation's business as presently conducted does no positive harm to anyone, but the modification and subsequent justification would accomplish the moral good of saving human lives.

The two approaches we consider are the ALI Principles of Corporate Governance and the "Integrative Social Contracts Theory" of marketplace morality developed by business ethicist Thomas Dunfee.

\section{a. Doing Good under the ALI Principles of Corporate Governance}

Under $\S 2.01$ (b) of the Principles of Governance, the corporation can decide to do good if doing so is (1) supported by an ethical consideration that is sufficiently recognized so as not to be idiosyncratic and (2) "reasonably regarded as appropriate to the responsible conduct of business.", 84

This issue is also at the crux of the whole "shareholder primacy" debate. See, e.g., Bainbridge, In Defense of the Shareholder Wealth Maximization Norm: A Reply to Professor Green, 50 WASH. \& LEE L. REV. 1423 (1993).

83. This hypothetical is taken from GERMAIN GRISEZ, THE WAY OF THE LORD JESUS: DIFFICULT MORAL QUESTIONS I 100, 453-59 (1997) [hereinafter GRISEZ, DIFFICULT MORAL QUESTIONS]. The hypothetical presents perhaps the extreme test of the "do good" issue because the beneficiaries of the drug are not, nor are they likely to ever be, investors or stakeholders in the corporation.

84. Depending on the size of the corporation, it might be that the corporation could treat the issue as one governed by $\S 2.01(b)(3)$ and devote a "reasonable amount of resources" to public welfare and humanitarian purposes. However, that provision includes a limitation as to the amount of the resources devoted, which the general ethical consideration fails to include. 
The first issue, then, is whether the notion that human lives should be saved even at the cost of utilizing corporate resources with no expectation of receiving commensurate returns is a broadly held ethical view. Perhaps the most troublesome aspect of the hypothetical is that the beneficiaries of the expenditures are not stakeholders in the corporation, which makes it difficult to support the expenditure based on the common good of the participants in the corporate community. ${ }^{85}$ On the other hand, Americans regularly espouse the belief that they "ought to" use their wealth to address avoidable suffering and death by regularly participating in, among other things, the universal outpourings of charity in response to natural disasters world-wide. Given such support for what amounts to a highly moral stance, it would seem that a manager could reasonably rely on that ethical consideration as one "broadly held" within the meaning of $\S 2.01(\mathrm{~b})$.

This analysis could be met with the objection that reducing shareholder returns to accomplish the modification results in an injustice because the common shareholders, as residual risk bearers, are entitled to that money. In other words, shareholders could object on the basis that the wealth is in fact rightly "theirs" on the basis of their residual right to maximized profits. That argument, however, assumes the very point at issue: $\S 2.01$ provides that the shareholders are entitled to the returns only if the modification cannot be justified under the two-part test. In other words, shareholders are entitled only to those returns that result after management exercises its discretion under $\S 2.01$.

The second prong of the ALI test, "appropriate to the responsible conduct of business," is more problematic. As comment (h) to $\S 2.01$ explains, managers are "dealing with other people's money," at least insofar as invested capital is concerned-the freedom to do good must presumably, then, be constrained. On the other hand, comment (h) also recognizes that corporate officials are not less morally obliged than the investors themselves to take moral considerations into account; the test then seems to turn less on what is meant by "appropriate," and more on what is meant by "responsible conduct of business." In other words, managers can take into account moral considerations that bear some relationship to the business as long as the considerations themselves are appropriate and the impact "responsible." The trouble raised by such a standard inevitably comes in defining the nature of that relationship, and in identifying what conduct counts as "responsible."

85. GRISEZ, DIFFICULT MORAL QUESTIONS, supra note 83 , at $456-57$. In primary reliance on this distinction, Grisez, applying a natural law analysis, finds that there is no obligation to cure the disease. 
The illustrations to $\S 2.01$ (b) do not directly answer these questions, but they do provide some insight. Certainly, the ALI must mean more than "rules of the game" (i.e., no lying or fraud), ${ }^{86}$ or the discretion would be trivial; however, it is equally clear that managers cannot appoint themselves a welfare agency doling out resources merely because the corporation has the resources. As to what is permissible, the most obvious example is an action intended to benefit investors other than shareholders (i.e. stakeholders) ${ }^{87}$ The illustrations to comments (h) and (i) of $\S 2.01$ are limited to that situation. Our drug distribution hypothetical, however, is more difficult than the illustrations because the beneficiaries in it are strangers, not stakeholders.

Does that mean that the diversion of resources to non-investors would be inappropriate or irresponsible? We think not. As comment (i) to $\S 2.01$ states, "Social policy ... favors humane behavior by major social institutions." The pharmaceutical company is uniquely situated to provide humanitarian relief because it already has the expertise and is apparently a major, if not sole, potential provider. It does not seem to be too great a stretch of the English language to say that a corporation in the business of making drugs and alleviating human suffering has an arguably prima facie moral right to engage in conduct that will prevent the death of tens of thousands of people who need a drug manufactured by that corporation. An obvious caveat, of course, is that the effort must not be out of proportion to corporate resources and profitability. Since the hypothetical illustrates double-digit percentages of income as an example, single-digit percentages would not seem unreasonable, and

86. $\S 2.01, \mathrm{cmt} . \mathrm{h}$, includes two illustrations. Illustration 11 states that a corporation may choose to honor a contract unenforceable under the Statute of Frauds even though the corporation is about to be dissolved. Illustration 12 states that the corporation can also refuse to honor the contract and assert the Statute as profit-maximizing behavior. The comment also refers to Illustrations 13, 14, 19 , and 20, which illustrate the application of $\S 2.01(b)(2)$ (permitting a corporation to devote a reasonable amount of resources to public welfare, humanitarian, educational, and philanthropic purposes).

87. The illustrations to $\S 2.01(b)(3)$ deal with such cases. Those illustrations also address the content of subsection $(b)(2)$. For example, Illustration 13 deals with a retirement annuity for an employee of a company about to be liquidated. Illustration 20 deals with a corporation that sells a money-losing plant, and approves of a short-term lease entered into at a loss in order to cushion the effect of a plant closure on long-term employees. Illustration 19, which deals with management's refusal to sell or close a money-losing plant in order to preserve jobs, is intended to set the outer perimeters of the humanitarian exception to profit-maximization. That illustration, however, is distinguishable from the present hypothetical because it involved an indefinite commitment and resulted in a loss of over $25 \%$ of the corporation's annual income. The illustration does state that the action cannot be justified under $\S 2.01$ (b)(2) because the corporation is not "obligated" to make the expenditure, but nowhere else in $\S 2.01$ or in the comment is there any indication that a moral obligation is a prerequisite to making an expenditure. 
physical provision of the drug appears to present no serious obstacle to the corporation's viability.

The conclusion that managers should be able to use corporate resources to do good in the limited and dramatic circumstances of the hypothetical is supported by two other considerations. First, it is consistent with the structuralist perspective of corporations: They are formed not just to make a profit and certainly not to make the highest profit, but to produce a good or service of which contributors to the enterprise can be proud and from which they receive personal satisfaction. ${ }^{88}$ Clearly, saving a significant number of lives should qualify under this perspective.

Second, permitting such managerial discretion is consistent with the contractual perspective of corporations. One of the residual risks that common shareholders assume is that the directors they elect will not be as competent or wise or good or mercenary as they expect. Permitting managers to exercise moral choices does not inherently alter the nature of that residual risk. Investors concerned only about profit-maximization can sell shares owned of unduly "do-gooding" companies, which will ultimately discipline management to align its actions with investors' moral preferences. In short, the open exercise of managerial discretion results in efficient and informed decision-making. ${ }^{89}$

\section{b. Doing Good under the Integrated Social Contracts Theory}

In contrast to the relatively unrestricted range of permissible moral considerations that may motivate managerial decisions suggested by the ALI Principles, Professor Dunfee supports a narrower version of permissible ethical behavior by corporations that is tied to what they perceive to be market discipline and universal norms. The "Integrative Social Contracts Theory" of "marketplace morality" is based on the conviction that neither the "Monotonists," who claim that managers must further the economic interests of only common shareholders, nor the "Pluralists," who would permit managers to take into account the interests of a broader group of investors, are correct in their analyses of the proper role of moral desires within the realm of corporate governance. $^{90}$

Dunfee holds instead that the focus of corporate governance in this area should be on "marketplace morality" because "moral desires are

88. This perspective is emphasized by Catholic Social Teaching. See infra Part III.

89. Professor Lawrence Mitchell makes this point forcefully, but from a different perspective, in Cooperation and Constraint in the Modern Corporation: An Inquiry into the Causes of Corporate Immorality, 73 TEX. L. REV. 477 (1995).

90. Dunfee, supra note 16, at 130-36. 
embodied in [both capital and consumer] markets." "Market morality" is the reflection of consumers' moral desires as evidenced in their decisions concerning current consumption. ${ }^{92}$ Against this background, Dunfee sets forth a series of principles as to when and how managers can take morality into account in ordering the corporation's business affairs:

1. It is presumed that all corporate actions must be undertaken to maximize shareholder wealth.

2. Managers must respond to and anticipate market morality that may have a negative impact on shareholder wealth. To identify relevant moral principles, managers should look to norms in their community, industry codes and similar sources.

3. Managers can rebut the presumption in favor of shareholder primacy where "clear and convincing evidence" exists that market morality would justify a decision that cannot be proved to maximize shareholder wealth.

4. Regardless of the impact on shareholder wealth, managers should act consistently with "mandatory hypernorms." Hypernorms are universally recognized moral obligations such as prohibitions on lying and stealing. ${ }^{93}$

Applying Dunfee's theory to our pharmaceutical hypothetical leads to the following conclusion: Managers would be precluded from causing the corporation to modify the drugs and save the lives unless they could demonstrate through "clear and convincing evidence" that the pharmaceutical consumer market would prefer that outcome and would modify their consumption decisions in favor of the corporation as a result.

We believe that the managers applying that test could not make the modification for two independent reasons. First, any such conduct would, ex hypothesi, breach the long-term profit-maximization rationale set out in (1). Any breach of that principle, however, as allowed under (3) requires "clear and convincing evidence that market morality" would justify that result. The very identification between market morality and the maximization rubric, however, is precisely the viewpoint challenged by this article. Unless that issue is decisively resolved, it is impossible to know whether market morality would justify a jettison of the maximization principle with "clear and convincing evidence." Hence,

91. Dunfee, supra note 16, at 129.

92. Dunfee, supra note 16, at 143.

93. Dunfee, supra note 16, at 149-50. 
under Dunfee's principles, the managers would not be permitted to engage in the proposed conduct.

Second, under (4), such conduct, even if it was not allowed under (3), could be permissible if the interest motivating the pharmaceutical company's hypothetical decision "in doing good" could be shown to function as a universal mandatory hypernorm. This, however, would require affirming that a corporate obligation exists to do good whenever and however one can, a rule which we do not here assert, to our knowledge has never been applied, and is in fact disfavored in the law. ${ }^{94}$

Dunfee's theory is thus even more restrictive than the ALI Principles when applied to the hypothetical. As such, it does not appear to grant sufficient moral authority to managers to exercise the moral responsibility of the corporation. By binding management to the goal of profitability, except in the case of indisputable market consensus or the observance of some vaguely defined "universal norms," the theory denigrates the right of managers to make ethical choices and transfers such judgment to the questionable but not purely hypothetical shareholder "market morality" demands for profitability. While such a position no doubt has its own logic, we suggest that it is in fact unnecessary from a business point of view, and should be rejected because it interferes with and alienates a manager from her own ethical responsibility as a moral actor.

\section{Synopsis}

In the preceding Part, we have attempted to state and briefly justify the following premises:

1. Corporations have the power and right to take moral considerations into account, even when doing so would harm investors' economic interests.

2. Corporations also have the obligation to take moral considerations into account, even when to do so would harm investors' economic interests.

3. Managers do not become amoral actors simply because they act as fiduciaries for corporate investors.

94. Although beyond the scope of this article's discussion, we do not deny that circumstances may arise in which a moral obligation of the corporation to act could sometimes arise. Our thesis in the present article is more limited. All we argue is that the right of the corporation to act exists even if there is no absolute moral obligation to act. 
4. Managers have a right to take their non-idiosyncratic ethical considerations and accompanying obligations into account in making a decision that would prevent the corporation from harming a third party, and investors cannot hold them liable for doing so even if the investors are economically disadvantaged by the decision.

5. Managers have a right to take their non-idiosyncratic ethical considerations and accompanying obligations into account in deciding whether the corporation should allocate resources to accomplishing a good reasonably related to the corporation's business.

In short, we conclude that whether one adopts a structuralist or contractarian view of the corporation, the corporation-as an institution with independent viability under law-must have moral responsibility. A corporation is capable of action contrary to the desires or interests of individual managers and investors, and thus is greater than the sum of its components. Conversely, to the extent that a manager, as an animator of the corporation, can avoid a harm or cause a good by means of corporate action and still sustain the operation of the corporation with a fair profit, the manager would presumptively be morally responsible for failing to avoid that harm or failing to accomplish that good.

\section{A PRIMER on CATHOLIC Social TEACHING}

Having drawn out the preceding argument favoring a place for substantial ethical thinking in the practical deliberations of corporate officers, we now proceed to consider whether the social teaching of the Catholic Church provides a fruitful source for guiding such moral reasoning and decision-making. We begin with a primer on Catholic Social Teaching and then apply some of its basic tenets to a selection of hypothetical Corporate Manager's Dilemmas.

The corpus of the Church's teachings on social and economic issues is rich and complex, and has been the subject of book-length treatments. ${ }^{95}$ For purposes of this essay, we attempt to provide only the barest outlines of the present state of the Church's teachings on the issues most relevant to our topic, leaving more detailed analyses to discussion of particular Manager's Dilemmas in Part IV.

95. The Church's social teaching goes back to its earliest days and reflects principles fundamental to the Judeo-Christian tradition. However, modern Catholic Social Teaching began with the promulgation in 1891 of Rerum Novarum, Pope Leo XIII's seminal discussion of the "social question." Pope Leo's principles have been elucidated and refined in encyclicals and addresses by later Popes and are now reflected both in the teachings of the Second Vatican Council and in the Catechism of the Catholic Church. 
Our efforts in this context will be based on only two relevant documents: first, Gaudium et Spes, The Pastoral Constitution on the Church in the Modern World, ${ }^{96}$ promulgated by the Second Vatican Council and proclaimed by Pope Paul VI on December 7, 1965; and second, Centesimus Annus, Pope John Paul II's 1991 encyclical on economic matters issued in commemoration of the $100^{\text {th }}$ anniversary of Rerum Novarum. ${ }^{97}$

Before proceeding to the specifics, it is necessary to say a few words about the nature, import and effect of the Church's social teaching. The Church and the Pope's pronouncements on social and economic matters "belong to the Church's doctrinal patrimony and, as such, involve the exercise of her teaching authority." "These principles of social teaching do not, however, include specific "analysis of events of recent history," which would not fall within the Magisterium's specific domain. ${ }^{99}$ Thus, the Church does not purport to be stating hard and fast rules applicable to each and every situation. Instead, it is clear that its social teaching sets forth principles of general guidance to assist in making prudential judgments regarding specific ethical situations.

\section{A. Gaudium et Spes}

The framework for Catholic Social Teaching as it applies to moral choices in business is set forth in Gaudium et Spes. This "Constitution" is the Church's explanation "to everyone how it conceives of the presence and activity of the Church in the world of today." 100 The Council compiled this constitution by "scrutinizing the signs of the times and interpreting them in the light of the Gospel."101 The basic philosophy of the document for our purposes can be summed up with the statement that "[h]uman institutions, both private and public, must labor to minister to the dignity and purpose of man."102

96. Second Vatican Council, Gaudium et Spes: Pastoral Constitution on the Church in the Modern World (1965), reprinted in THE SIXTEEN DOCUMENTS OF VATICAN II (Nat'l Catholic Welfare Conference trans., St. Paul ed. 1967) [hereinafter Gaudium et Spes].

97. Pope Leo XIII, Rerum Novarum: Encyclical Letter on Capital and Labor (St. Paul ed. 1991) [hereinafter Rerum Novarum].

98. Pope John Paul II, Centesimus Annus: Encyclical Letter on the Hundredth Anniversary of Rerum Novarum 13 (St. Paul ed. 1991) [hereinafter Centesimus Annus].

99. Id.

100. Gaudium et Spes, supra note 96 , at $\$ 2$.

101. Gaudium et Spes, supra note 96, at 4.

102. Gaudium et Spes, supra note 96, at ๆ 29. See also Gaudium et Spes, supra note 96, at $\mid 63$ ("In the economic and social realms, too, the dignity and complete vocation of the human person and the welfare of society as a whole are to be respected and promoted. For man is the source, the center, and the purpose of all economic and social life."); COMPENDIUM OF THE SOCIAL DOCTRINE OF THE CHURCH (CSDC) $\{331$ (2004). Parallel cites to the CSDC will be provided where appropriate. 
The Council did not specifically address the role of corporations in society or specific matters of business ethics, though Gaudium et Spes is explicit in its promotion of the good of economic growth and in its respect for the autonomy of economic life within the overall moral order:

[T]echnical progress, an inventive spirit, an eagerness to create and to expand enterprises, the application of methods of production, and the strenuous efforts of all who engage in production-in a word, all the elements making for such development-must be promoted. The fundamental finality of this production is not the mere increase of products nor profit or control but rather the service of man, and indeed of the whole man with regard for the full range of his material needs and the demands of his intellectual, moral, spiritual, and religious life; this applies to every man whatsoever and to every group of men, of every race and of every part of the world. Consequently, economic activity is to be carried on according to its own methods and laws within the limits of the moral order, so that God's plan for mankind may be realized. ${ }^{103}$

The Council, however, was also explicit in its statement that all property is held for the common good:

Whatever the forms of property may be . . attention must always be paid to this universal destination of earthly goods. In using them, therefore, man should regard the external things that he legitimately possesses not only as his own but also as common in the sense that they should be able to benefit not only him but also others. On the other hand, the right of having a share of earthly goods sufficient for oneself and one's family belongs to everyone. The Fathers and Doctors of the Church held this opinion, teaching that men are obliged to come to the relief of the poor and to do so not merely out of their superfluous $\operatorname{goods} . . .{ }^{104}$

In sum, when the Second Vatican Council looked out at the world of business, it was certainly not hostile to economic institutions, economic growth, or notions of private property. Nevertheless, the

103. Id. at If 64 (emphasis added) (internal citations omitted). While the document recognizes that economic activity is to be carried out according to "its own methods," the Council suggested that shareholder primacy is not the appropriate end-result:

In economic enterprises it is persons who are joined together, that is, free and independent human beings created to the image of God. Therefore, with attention to the functions of each—owners or employers, management or labor - and without doing harm to the necessary unity of management, the active sharing of all in the administration and profits of these enterprises in ways to be properly determined is to be promoted.

Id. at $\uparrow 68$.

104. Id. at $\{69$ (emphasis added) (internal citations omitted); CSDC at 178. 
Council explicitly affirmed that economic institutions exist for the common good, that human dignity is the goal and highest value of economic activity, and that private property and returns from economic activity must be used to benefit all.

\section{B. Pope John Paul II and Centesimus Annus}

In his 1991 encyclical letter Centesimus Annus, Pope John Paul II, though focusing to a significant extent on macro-economic conditions and systems and the rights and obligations of States, had much to say about the rights and obligations of individuals and organizations involved in economic activity. ${ }^{105}$ The encyclical first revisits Rerum Novarum, from which it draws several fundamental principles of continued relevance today. These include the fundamental importance of "the human person's transcendent dignity," 106 the qualified right to own private property, ${ }^{107}$ and the limits on freedom of contract necessary to protect those with limited bargaining power. ${ }^{108}$

Overall, John Paul II's interpretation of Rerum Novarum places great emphasis on the obligation to act in accordance with the principle Leo XIII called "friendship" and which John Paul refers to as "solidarity" in order to create, in the words of Pope Paul VI, a "civilization of love." 109 "[T]he State has the duty of watching over the common good and of ensuring that every sector of social life, not excluding the economic one, contributes to achieving that good, while respecting the rightful autonomy of each sector." 110 The State, however, is not expected to solve every social problem; rather, it exists to protect, not stifle, the rights of individuals, families, and society. ${ }^{111}$

In general, John Paul II favors corporate organizations and holds that they can serve the common good:

According to Rerum Novarum and the whole social doctrine of the Church, the social nature of man is not completely fulfilled in the State, but is realized in various intermediary groups, beginning with the family and including economic, social, political and cultural groups

105. Centesimus Annus, supra note 98 , at $\uparrow 3$.

106. Centesimus Annus, supra note 98 , at 95 .

107. Centesimus Annus, supra note 98 , at $\$ 6$.

108. Centesimus Annus, supra note 98, at 77.

109. Centesimus Annus, supra note 98, at 10 (quoting Rerum Novarum, supra note 97, at 114-16, and Pope Paul VI's Message for the 1977 World Day of Peace, AAS 68, 709 (1976)); CSDC at $₫ 103$.

110. Centesimus Annus, supra note 98, at 11.

11. Centesimus Annus, supra note 98, at 11 . 
which stem from human nature itself and have their own autonomy, always with a view towards the common good. ${ }^{12}$

He views this issue through the lens of "a 'community of work' which embraces ever-widening circles." 113 Although not mentioning corporations explicitly, he provides an excellent description of their role in society:

A person who produces something other than for his own use generally does so in order that others may use it after they have paid a just price, mutually agreed upon through free bargaining. It is precisely the ability to foresee both the needs of others and the combinations of productive factors most adapted to satisfying those needs that constitutes another important source of wealth in modern society. Besides, many goods cannot be adequately produced through the work of an isolated individual; they require the cooperation of many people in working towards a common goal. Organizing such a productive effort, planning its duration in time, making sure that it corresponds in a positive way to the demands which it must satisfy, and taking the necessary risks-all this too is a source of wealth in today's society. In this way the role of disciplined and creative human work and, as an essential part of that work, initiative and entrepreneurial ability becomes increasingly evident and decisive.

This process . . should be viewed carefully and favourably. ${ }^{114}$

Centesimus Annus implicitly recognizes that corporations have positive characteristics by affirming those aspects of the "modern business economy" which could not exist without such large multinational and publicly held organizational forms, ${ }^{115}$ though the encyclical is also quite clear that the fundamental normative basis of corporate existence is "human freedom exercised in the economic field," and that this freedom must be exercised responsibly. ${ }^{116}$ Responsible exercise of human freedom in a business setting, however, must recognize in the first place that that very freedom is exercised and made possible only in the context of and because of a preexisting solidarity of the common human enterprise. Corporations do not exist in a vacuum. Such freedom is therefore ethically limited by certain basic demands: First, of course, that the corporation do no harm to the common good; but second, that the corporation help and aid the common human

112. Centesimus Annus, supra note 98, 13 (emphasis added).

113. Centesimus Annus, supra note 98, at 9 32; CSDC at 337 .

114. Centesimus Annus, supra note 98 , at $\$ 32 ; \mathrm{CSDC}$ at $\$ 337$.

115. Centesimus Annus, supra note 98, at ๆ 32 ; CSDC at 9337.

116. Centesimus Annus, supra note 98 , at $\$ 32 ; \mathrm{CSDC}$ at $\$ 337$. 
endeavor when possible and reasonable in light of its resources. Integral business practice, therefore, cannot in principle exclude the obligation and right of a business and its actors to manage economic pursuit of wealth and property in a manner consistent with the needs of the human community.

It is often true that the most obvious and pressing need manifests itself in the conditions of marginalized members of the community created by the corporation's own actions. Indeed, as an example of this responsibility, the John Paul II refers explicitly to the potential harms flowing from corporate restructurings:

[T] he constant transformation of the methods of production and consumption devalues certain acquired skills and professional expertise, and thus requires a continual effort of retraining and updating. Those who fail to keep up with the times can be easily marginalized, as can the elderly, the young people who are incapable of finding their place in the life of society and, in general, those who are weakest or part of the so-called Fourth World. The situation of women too is far from easy in these conditions. ${ }^{117}$

Thus, profit is not the be all and end all, but rather is a regulator of economic life:

[T] he purpose of a business firm is not simply to make a profit, but is to be found in its very existence as a community of persons who in various ways are endeavoring to satisfy their basic needs, and who form a particular group at the service of the whole of society. Profit is a regulator of the life of a business, but it is not the only one; other human and moral factors must also be considered which, in the long term, are at least equally important for the life of a business. ${ }^{18}$

Catholic Social Teaching thus recognizes that an overly aggressive search for profits causes human alienation from the corporation and from others in society when work is organized to ensure maximum returns and profits with little or no concern for whether the worker, through his own labor, grows or diminishes as a person. ${ }^{119}$

\section{APPlying Catholic Social Teaching to SPECIFIC Situations}

The Church teaches that Catholic Social Teaching has application in all circumstances at all times. ${ }^{120}$ However, the Church also recognizes that its teaching in the area of business ethics is, with regard to any but

117. Centesimus Annus, supra note 98 , at $\$ 33$.

118. Centesimus Annus, supra note 98 , at $\$ 35$ (emphasis added).

119. Centesimus Annus, supra note 98 , at 941 .

120. Centesimus Annus, supra note 98 , at $\$ 46$. 
the most basic issues (e.g., "Don't Lie, Cheat or Steal"), very conceptual, so that its application in any particular business circumstance is a matter of prudential judgment. ${ }^{121}$ In this Part, we apply Catholic Social Teaching to specific managerial dilemmas to demonstrate how it can provide workable principles that can assist the manager in addressing her dilemma while not dictating a simplistic answer.

The discussion in this Part is based on the following hypothetical:

Aaron Industries manufactures parts for automobiles. It is headquartered in Midway, Ohio, where it has operated a plant since 1946. The plant is the largest single employer in Midway, and it has been estimated that $20 \%$ of Midway's 30,000 jobs are dependent on the Aaron plant. Aaron also operates plants in California, Missouri, and Malaysia.

In 1989 Moses International acquired Aaron in a leveraged buyout that took Aaron private and created a large amount of debt on Aaron's balance sheet. In 1998, Moses spun off Aaron into a publicly held company, and its stock is now traded over the counter and quoted on NASDAQ. However, the proceeds of the public stock offering did not eliminate all the acquisition debt. As a result of that debt, reduction in demand for Aaron's products, and increased foreign competition, Aaron's after-tax earnings have fallen $62 \%$ over the last three years. Nevertheless, Aaron remains profitable with an after-tax return on equity of $9 \%$, which compares to a peer average of $12 \%$. Its revenues exceed $\$ 5$ billion per year and its annual net profits after taxes last year were $\$ 230$ million.

Aaron is managed by a board of directors consisting of eight outside and six inside directors. Four of the outside directors and three of the insiders predate the Moses acquisition, have lived in Midway all their professional lives, and are actively involved in civic affairs. The remaining inside directors are holdovers from the Moses years, and the remaining outside directors are CEOs of other large companies in the region.

\section{Case 1: Employee Stock Ownership Plan}

Before the Moses acquisition, Aaron had a two-part employee stock ownership plan. Pursuant to Part A of the Plan, the company annually distributed shares with a total market value equal to $10 \%$ of the year's profits to employees. The shares were allocated according to a formula based on years of service and annual compensation. Part B of the Plan 
permitted employees to purchase additional shares at a $10 \%$ discount from market price. Aaron would contribute $25 \%$ of the price of any such shares under the optional purchase plan.

The four outside directors from the pre-Moses years have requested that the Vice President of Human Resources evaluate whether Aaron should now adopt a similar plan. The Vice President's investigation shows the following:

- Part A of the Plan would cost Aaron (i.e., reduce the retained earnings otherwise available to owners of shares not within the Plan) \$16 million per year;

- Part B would cost Aaron $\$ 12$ million per year, assuming the same rates of participation that Aaron experienced under the prior Plan;

- Aaron's employees' compensation already ranks in the 90th percentile of its peer group; and

- The Plan would dilute the interests of non-employee shareholders.

Analysis:

Catholic Social Teaching generally supports stock ownership plans for employees. Various encyclical statements range from the permissible to the obligatory. Pope Pius XI, for example, in Quadragesimo Anno, ${ }^{122}$ asserted:

We consider it more advisable, however, in the present condition of human society that, so far as is possible, the work-contract be somewhat modified by a partnership-contract, as is already being done in various ways and with no small advantage to workers and owners. Workers and other employees thus become sharers in ownership ... or participate in some fashion in the profits received. ${ }^{123}$

Pope John XXIII later expanded on this thought in Mater et Magistra: ${ }^{124}$

We must notice ... the system of self-financing adopted in many countries by large, or comparatively large firms. Because these companies are financing replacement and plant expansion out of their own profits, they grow at a very rapid rate. In such cases We believe

122. Pope Pius XI, Quadragesimo Anno: Encyclical Letter on Reconstruction of the Social Order (St. Paul ed. 1995) [hereinafter Quadragesimo Anno].

123. $I d$. at $\uparrow 65$.

124. Pope John XXIII, Mater et Magistra: Encyclical Letter on Christianity and Social Progress (St. Paul ed. 1991) [hereinafter Mater et Magistra]. 
that the workers should be allocated shares in the firms for which they work, especially when they are paid no more than a minimum wage.

We should recall here the principle enunciated by Pius XI in Quadragesimo Anno: "It is entirely false to ascribe to the property alone or to the work alone whatever has been obtained through the combined effort of both, and it is wholly unjust for either, denying the efficacy of the other, to arrogate to itself whatever has been produced."

Experience suggests many ways in which the demands of justice can be satisfied. Not to mention other ways, it is especially desirable today that workers gradually come to share in the ownership of their company, by ways and in the manner that seem most suitable. For today, even more than in the time of Our Predecessor, "every effort must be made that at least in the future a just share only of the fruits of production be permitted to accumulate in the hands of the wealthy, and that an ample sufficiency be supplied to the workers." ${ }^{\text {125 }}$

In more recent times, Pope John Paul II has affirmed the right of workers to participate in the ownership of the companies for which they work. In Laborem Exercens, ${ }^{126}$ Pope John Paul II reached this conclusion in light of the objective order of earthly goods "laid down from the beginning" as reflected in the Book of Genesis: Man is the highest good in the natural order of creation, since he alone "is made to be in the visible universe an image and likeness of God" and is "placed in it in order to subdue" the rest of the created order. ${ }^{127}$ Consequently, it is a disorder if "man is treated as an instrument of production": ${ }^{128}$ That is, it is wrong to use man as an instrument to achieve some further end, since man is the highest end of the created order. Because all of creation was made to serve man, man has a certain right to the ownership or use of that creation, but even here a certain order must be observed: "[T]he right to private property is subordinated to the right to common use, to the fact that goods are meant for everyone." ${ }^{29}$ From this, Pope John Paul II concluded that "in consideration of . . . [the] common access to the goods meant for man, one cannot exclude the socialization, in suitable conditions, of certain means of production." 130 The Pope provided concrete examples of what this process of socialization entails:

125. Id. at if 75-77.

126. Pope John Paul II, Laborem Exercens: Encyclical Letter on the Ninetieth Anniversary of Rerum Novarum (St. Paul ed. 1989) [hereinafter Laborem Exercens].

127. Id. at Preamble.

128. Id. at 77 .

129. Id. at 14; CSDC at 177.

130. Laborem Exercens, supra note 126, at ๆ 14; CSDC at 1177. 
In light of the above, the many proposals put forward by experts in Catholic Social Teaching and by the highest Magisterium of the Church take on special significance: Proposals for joint ownership of the means of work, sharing by the workers in the management and/or profits of business, so-called shareholding by labor, etc. Whether these various proposals can or cannot be applied concretely, it is clear that recognition of the proper position of labor and the worker in the production process demands various adaptations in the sphere of the right to ownership of the means of production....

We can speak of socializing only when the subject character of society is ensured, that is to say, when on the basis of his work each person is fully entitled to consider himself a part-owner of the great workbench at which he is working with everyone else. A way toward that goal could be found by associating labor with the ownership of capital, as far as possible, and by producing a wide range of intermediate bodies with economic, social, and cultural purposes; they would be bodies enjoying real autonomy with regard to the public powers, pursuing their specific aims in honest collaboration with each other and in subordination to the demands of the common good, and they would be living communities both in form and in substance, in the sense that the members of each body would be looked upon and treated as persons and encouraged to take an active part in the life of the body. ${ }^{131}$

For Pope John Paul II, then, respect for the objective order of goods and their universal destination requires, to the extent it is practically and prudently feasible, that laborers participate in the ownership of the company through employee share plans or other appropriate means. ${ }^{132}$

131. Laborem Exercens, supra note 126, at I14; CSDC at 177.

132. Consistently, the U.S. Bishops also encourage increased ownership by workers in the companies for which they work:

Workers in firms and on farms are especially in need of stronger institutional protection, for their jobs and livelihood are particularly vulnerable to decisions of others in today's highly competitive labor market. Several arrangements are gaining increasing support in the United States: profit sharing by the workers in a firm; enabling employees to become company stockholders . . . cooperative ownership of the firm by all who work within it; and programs for enabling a much larger number of Americans, regardless of their employment status, to become shareholders in successful corporations. Initiatives of this sort can enhance productivity, increase the profitability of firms, provide greater job security and work satisfaction for employees, and reduce adversarial relations. In our 1919 Program for Social Reconstruction, we observed "the full possibilities of increased production will not be realized so long as the majority of workers remain mere wage earners. The majority must somehow become owners, at least in part, of the instruments of production. We believe that this judgment remains generally valid today."

National Conference of Catholic Bishops, Economic Justice for All, Pastoral Letter on Catholic Social Teaching and the U.S. Economy $\mid 300$ (USCCB Office of Publishing and Promotion Services 1986) (citations omitted) [hereinafter Economic Justice for All]. 
Applying these general statements to the particular issue of employee stock ownership plans could reasonably lead to the following analysis: Workers now participate in the fruits of the corporate community through their compensation, which ranks in the $90^{\text {th }}$ percentile of compensation paid by comparable companies. If the encyclicals view ownership of the means of production as merely one way to achieve just remuneration for work, then the Vice President could reasonably conclude that no stock plan is necessary, or that if one is adopted, other compensation should be reduced.

On the other hand, the Vice President could understand the encyclicals to mean that stock ownership plans are a right to which every worker is entitled because of that worker's dignity as a human person. For example, Pope John Paul II speaks of the "right to ownership of the means of production." 133 This right seems to be indispensable for what he calls the socialization of property and to stand independently of compensation, but given the value the Pope places on ownership as such, it appears unlikely that ownership of the means of production can be replaced by generous compensation. ${ }^{134}$ As one example of the distinction between the two, stock ownership provides not only financial rights, but also voting rights that permit the employee to participate in corporate governance.

Taking the encyclical statements as a whole, it would not be unreasonable for the Vice President to recommend that the stock option plan be viewed as a necessary part of an employee's compensation and to advise that participation in the plan be contingent on acceptance of the benefits in lieu of a commensurate part of the employee's other compensation. ${ }^{135}$ The encyclicals, for the most part, view shareholding by labor not as an absolute right, but as a prudential way to achieve justice under prevailing conditions. As Pope John XXIII asserted, "[e]xperience suggests many ways in which the demands of justice can be satisfied," and shareholding by labor is merely one of those ways, albeit one the popes clearly encourage. ${ }^{136}$

This is not to say that it would be unreasonable for the Vice President to decide that adoption of the plan is not supported by ethical considerations. John Paul II seems to acknowledge this possibility when he says that the ideal of shareholding by labor may or may not be applied

133. Laborem Exercens, supra note 126, at If 14.

134. Note that this is seemingly inconsistent with earlier papal statements that view share ownership, not with intrinsic value, but merely as a means to achieve just remuneration of work.

135. Of course, employees may not be amenable to such a swap, but the question for the manager is whether there is an ethical consideration that requires/supports offering the opportunity to participate in the plan.

136. Mater et Magistra, supra note 124 , at $\$ 77$. 
concretely, but that "recognition of the proper position of labor and the worker in the production process demands various adaptations."137 Indeed, the Enron fiasco demonstrates that employees might not be better off if they invest too much of their assets into Aaron's stock. Many Enron employees lost most or all of their savings when their investments in company stock through the employee purchase plan were wiped out by Enron's bankruptcy. ${ }^{138}$ For this reason, Aaron might decide in the alternative not to adopt the optional part of the program, to limit employee purchases, or, at a minimum, to provide financial planning advice to employees who allocate more than a given percentage of their earnings to stock purchases.

\section{Case 2: Relocation of Midway Plant Operations to Malaysia}

The Midway plant requires higher maintenance than the industry average, substantial re-tooling for Aaron's new products, and higher wage costs than other plants. A consultant's study recommends the Midway plant be closed and production shifted to Aaron's Malaysia plant. The study also recommends that Aaron focus its future product manufacturing abroad to take advantage of the much lower wage costs and taxes in Malaysia. Wage costs in Malaysia are 30\% of wage costs in Midway, and benefits costs are only $8 \%$ of those incurred at Midway. Projected savings from the closure would be $\$ 82$ million over five years, with a present value of $\$ 63$ million. Those savings, however, do not take into account any costs related to termination benefits for Midway employees or mitigation of any loss to the Midway community. The estimates also assume that Aaron will pay market rates in Malaysia.

\section{Analysis:}

This situation urges a prudent businessperson to keep several principles in mind. Two separate analyses need to be made, as the closing of the Midway plant and the opening of Malaysia plant present different considerations. Each plant will be treated in turn.

137. Laborem Exercens, supra note 126, at 9 14. John Paul II also mentions that profit sharing with laborers is a permissible way to achieve the socialization of property. Thus, fair compensation (which may be, but is not necessarily, indicated by pay in the $90^{\text {th }}$ percentile) may not only constitute a substitute for a stock plan, but may help achieve another normative goal: the ability of labor providers to attain their equitable share of the socialization of property.

138. Christine Dugas, Enron's Dive Destroys Workers' Pensions, USA TODAY, Feb. 6, 2002, at $3 \mathrm{~B}$, available at http://www.usatoday.com/money/energy/2002-02-06-enron-pensions.htm. 


\section{Midway issues:}

Aaron should keep "solidarity" and the "common good" in mind when considering whether and how to close its facility. Solidarity, for purposes of this treatment, is defined as a bond among human beings that is derived from and recognized because of "our common origin and by the equality in rational nature of all men, whatever nation they belong to." 139 Solidarity is found across socio-economic lines, and should be manifest in many forms: "Solidarity of the poor among themselves, between rich and poor, of workers among themselves, between employers and employees in a business, solidarity among nations and peoples." ${ }^{40}$ How this principle is borne out in concrete factual patterns will be explored throughout this hypothetical.

Aaron has strong ties to the Midway community, and it has been an integral part of the economy dating as far back as 1946 . The number of jobs the company provides in Midway is significant as well-Aaron is currently the single largest employer-and the ramifications to the community from the closure of Aaron's plant will be considerable. This is not to say that a closure does not make good economic sense, or that Catholic social principles dictate that Aaron must keep the plant open. Indeed, the impact on the entire company could be far more significant if Aaron does not make some kind of drastic change to its operation. As pointed out in the fact pattern, the company operates with profits $3 \%$ lower than similar companies, has a significant amount of debt, needs to substantially re-tool the facility in Midway to keep it efficient, and faces falling product demand with increased foreign competition.

There seems to be no easy answer for a company in these circumstances, though solidarity requires that Aaron keep the community interests in mind when making its decision. All of the workers currently employed in Midway, several of the executives with residential and civic ties, and many of those dependent upon Aaron in the community will suffer greatly from the closing of the plant. The Catholic principle of solidarity, in conjunction with the golden rule of ethics ("do unto others as you would have them do unto you"), demands that Aaron recognize the good that the community in general has done for it, specifically the positive impact the workers have had on the company. ${ }^{141}$ This good is a product of the union of worker and employer, of community and business; it is a product of solidarity. Aaron did not achieve its success, and continuing profitability, in a vacuum. The hard work of Midway

139. CATECHISM OF THE CATHOLIC CHURCH I 1939 (2d ed. 1997) [hereinafter CCC] (quoting Pius XII, Summi Pontificatus, AAS 31, Oct. 20, 1939).

140. Id. at 1941.

141. Id. at 92407 . 
employees and the support of the community enabled this plant to remain viable for numerous years.

Again, this is not to say that Aaron is forbidden from closing this plant. If financial considerations compel decision-makers to relocate, and if Aaron takes other considerations into account with respect to opening a plant in another country, then the decision to move may be both economically and morally acceptable. If economic rationales strongly favor transfer of the operations, the key issue, not irrelevant to the economic factors, is in the "how" of the plant closing.

If the decision is made to transfer operations to Malaysia, Aaron can recognize the contribution of Midway to the company in a number of ways. It would, for example, be appropriate for Aaron to seek out other uses for the facility within its own company. Any jobs that may be provided by a more limited or alternative use would lessen the impact to the community, and might ensure some positions for those higherranking employees that might have the opportunity to relocate, but do not wish to. Aaron might also be able to find a use for the facility outside of the company. Aaron is bound to have contact with numerous companies that may wish to utilize the facility. These suggestions are not meant to be exhaustive or mandatory, but the company clearly has some ethical obligation to put significant effort toward openly working with the community to lessen the impact of its decision. Aaron should certainly expend a significant amount of resources in this effort, but not so much that it compromises the profitability of the company or strains the ability of the corporation to meet its other obligations. Needless to say, there are economic justifications that support aiding the community as well. Positive press and continued or increased support of Aaron in the Midwest are just a few potential results that may help sustain long-term profitability.

Aaron's decision should also take into account "the common good." The common good is "the sum total of social conditions which allow people, either as groups or individuals, to reach their fulfillment more fully and more easily." 142 There are numerous groups and communities that Aaron will affect with the action it takes in regard to the Midway plant. Some parties might benefit from the closure of the plant, while others will be in a better position if the plant remains active.

Consideration of the common good demands an honest assessment of major groups that are to be impacted by the plant closing. Again, prudence and reasonableness are the standards and, where possible, a businessperson should attempt to find a solution that will leave the

142. Id. at ๆ 1906 (citing Gaudium et Spes, supra note 96, at $\ 26$ ). 
greatest number of those affected in the best possible position. While it is impossible to satisfy every person and group, it is still possible for a company to compromise where it can to minimize, to one degree or another, the negative consequences to most parties.

If closure of the plant is necessary, the company should seek to find a way to secure the future of the company and current employees, while simultaneously lending significant aid to the community in Midway. This means that some short-term sacrifices will have to be made toward the immediate profit goals of the company, but the long-term effects of a humane plant closure may far outweigh those costs. This aid can come in the form of significant job-search assistance, reasonable compensation packages to laid-off employees, or the development of other opportunities within the company. Catholic Social Teaching does not require Aaron to achieve these goals in a way that threatens its viability, nor does it require that these efforts continue indefinitely, but a failure to recognize the employment needs of the Midway community would be contrary to the common good.

\section{Malaysia issues:}

Aaron has a recommendation from its consultant to open a replacement plant in Malaysia. The projected savings from such a move, without considering the costs of compensating Midway employees, is thought be $\$ 63$ million at present value. In deciding whether or not to open this new facility, the company should keep the universal destination of goods and the inherent dignity of the human person in mind.

The Catholic Church teaches that human beings are stewards of the earth, and that this brings with it certain responsibilities:

God entrusted the earth and its resources to the common stewardship of mankind to take care for them, master them by labor, and enjoy their fruits. The goods of creation are destined for the whole human race. However, the earth is divided up among men to assure the security of their lives, endangered by poverty and threatened by violence. The appropriation of property is legitimate for guaranteeing the freedom and dignity of persons and for helping each of them to meet his basic needs and the needs of those in his charge. ${ }^{143}$

The universal destination of goods, and the resulting respect for the integrity of creation, means that individuals and corporations alike must take steps to ensure that they are using the capital in their care in the proper way. Far from implying a Marxist or socialist schema, this requirement means that a prudent businessperson should operate the 
facility in a lesser-developed or unregulated country in a way that does not unduly damage the surrounding environment. In other words, Aaron should not seek to build the plant in Malaysia merely to take advantage of the unreasonable laxity or entire absence of environmental standards, especially where doing so would knowingly or recklessly lead to environmental damage or health risks. Although legitimate arguments may be made that some current United States standards are overly burdensome and ineffective, many are in fact reasonable, aimed at the health of citizens, and should be observed regardless of codified law. The Church states:

Animals, like plants and inanimate beings, are by nature designed for the common good of past, present, and future humanity. Use of mineral, vegetable, and animal resources of the universe cannot be divorced from respect for moral imperatives. Man's dominion over inanimate and other living beings granted by the Creator is not absolute; it is limited by concern for the quality of life of his neighbor, including generations to come[.]"144

Aaron must also consider the impact of its policies on its Malaysian employees and their families and communities. Aaron's consultant has determined that, with market wages, the company will be able to pay $30 \%$ of what it pays employees at Midway, and will only be required to pay $8 \%$ of benefit costs. Wages paid to workers in other countries are often the subject of heated debate, and far too often individuals examine the disparity in the wage figure between the two cultures, and overlook the difference in the relative costs of living. Considerations of the inherent dignity of the human person and the "living wage" can provide a businessperson with workable guidelines.

First, a "system in which social relationships are determined entirely by economic factors is contrary to the nature of the human person and his acts." 145 The Church also teaches that "[a] theory that makes profit the exclusive norm and ultimate end of economic activity is morally unacceptable . . . A system that 'subordinates the basic rights of individuals and of groups to the collective organization of production' is contrary to human dignity. Every practice that reduces persons to nothing more than a means of profit enslaves man[.]"146

Human beings must be seen as more than just another capital category, and must be treated as individuals with inherent dignity:

144. CCC, at 2415.

145. Id. at $\$ 2423$ (citing Centesimus Annus, supra note 98, at $\$ 24$ ).

146. Id. at $\$ 2424$ (citing Gaudium et Spes, supra note 96, at \ר 63, 65; Laborem Exercens, supra note 126, at If 7, 20; Centesimus Annus, supra note 98, at ף 35). 
Those responsible for business enterprises are responsible to society for the economic and ecological effects of their operations. They have an obligation to consider the good of persons and not only the increase of profits. Profits are necessary, however. They make possible investments that ensure the future of a business and they guarantee employment. ${ }^{147}$

All of this demands that the workers in Malaysia be able to work in conditions that are fitting for human labor. If the conditions found in factories in the United States most appropriately represent humane conditions for work, then the U.S. model should be the configuration put into place in Malaysia. Regardless of the particular model, substandard working conditions are unacceptable even if they are legally permissible and the norm for a particular locale.

As to the wages to be paid to workers, neither a particular pay scale nor a requirement of equal pay across global borders is recommended by the Catholic Church. Instead, what is demanded is a just wage:

In determining fair pay both the needs and the contributions of each person must be taken into account. "Remuneration for work should guarantee man the opportunity to provide a dignified livelihood for himself and his family on a material, social, cultural, and spiritual level, taking into account the role and productivity of each, the state of the business, and the common good." 48

In determining how much to pay Malaysian workers, Aaron should disregard the market figure and compute the wage as that which would allow a person to live a life of dignity. This means that Aaron should pay the workers a wage sufficient to allow them to maintain a becoming home (of whatever appropriate character), to eat enough to maintain a healthy lifestyle, and to spend some significant part of their day and week away from work and with their families.

The benefits that Aaron might pay out to the Malaysian workers are more substantive than simply the wage. The benefit system should also be in accord with human dignity, and Aaron should provide the workers with a reasonable benefits package. Because benefits vary so widely in the United States, the particulars and nuances of a Malaysian structure are impossible to anticipate in this treatment. At the very least, it should not be limited solely because the company is able to get away with providing less.

147. Id. at ๆ 2432 (citing Centesimus Annus, supra note 98, at ๆ 37).

148. Id. at 2434 (quoting Gaudium et Spes, supra note 96, at ๆ 67); CSDC at If 302. 


\section{Case 3: Employee Outsourcing}

Aaron's Board has directed management to take all steps necessary to maintain profitability in the more competitive business environment that lies ahead and to control its expenses to the maximum. Many of Aaron's labor costs are fixed under collective bargaining agreements with its unionized employees. However, Aaron's office employees are not unionized. Aaron's management consultant has proposed that all permanent hourly workers be fired, and then hired as contract workers by a "Professional Employer Organization ("PEO"). Aaron would then contract with the PEO to perform the services previously performed by the individual employees, and the PEO would use the former Aaron employees to fulfill its contract with Aaron. This structure would enable Aaron to slash its healthcare and retirement benefits costs, which would not be factored into the contract basis services.

\section{Analysis:}

The outsourcing of non-unionized employees touches upon several principles of Catholic thought. A prudent businessperson should consider the "inherent dignity of the human person" and "commutative justice" when deciding upon such a course of action. ${ }^{149}$

The Church teaches that unemployment "almost always wounds its victim's dignity and threatens the equilibrium of his life. Besides the harm done to him personally, it entails many risks for his family." 150 To discharge employees is a serious matter, and workers should not be viewed as mere statistics in cost-saving categories. As mentioned in Case 1 above, "a system that 'subordinates the basic rights of individuals and of groups to the collective organization of production' is contrary to human dignity. Every practice that reduces persons to nothing more than a means of profit enslaves man." "I51 It is important for Aaron to keep these things in mind when deciding upon outsourcing.

As discussed above, "[j]ustice toward men disposes one to respect the rights of each and to establish in human relationships the harmony

149. CCC at $\{2411$ (emphasis in original):

[C]ommutative justice... regulates exchanges between persons and between institutions in accordance with a strict respect for their rights. Commutative justice obliges strictly; it requires safeguarding property rights, paying debts, and fulfilling obligations freely contracted. Without commutative justice, no other form of justice is possible. One distinguishes commutative justice from legal justice which concerns what the citizen owes in faimess to the community, and from distributive justice which regulates what the community owes its citizens in proportion to their contributions and needs.

150. Id. at 2436 (citing Laborem Exercens, supra note 126, at 1 18); CSDC at 289.

151. CCC at I 2424 (citing Gaudium et Spes, supra note 96, at 9ा 63, 65; Laborem Exercens,

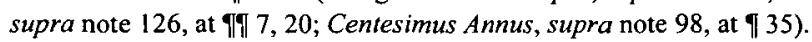


that promotes equity with regard to persons and to the common good."152 For Aaron, the business prerogative to hire and fire employees is appropriately exercised under ordinary circumstances. In this situation, it appears that the company may, in effect, be retaining the same employees at a reduced cost. There is nothing inherently wrong with this arrangement if the PEO provides comparable wages and benefits; if, however, Aaron is capitalizing on employees' need for jobs, and if the company felt that the wages paid to them as direct employees were fair, it may be contrary to their dignity for Aaron to ask them to do the same work for less.

While it is true that, under appropriate circumstances, Aaron may fire these employees to reduce costs, here Aaron is creating a plan that allows it to retain its employees' skill and experience in the factory. The situation would be different if (a) studies showed that the employees were being paid at a rate in excess of that justly attributable to their productivity, or (b) Aaron were confronted with a change in circumstances more fundamental than a mere desire to make more money, but in the absence of such a justification, it would not be just to pay employees less to do the same work.

\section{Case 4: Producing a "Philanthropic Drug"}

In Part I, we presented a hypothetical originally developed by Germain Grisez concerning managers of a pharmaceutical company who are faced with a dilemma of whether to incur expenditures of corporate resources to modify a patented drug and distribute it in Africa to combat a disease that only its drug could cure or prevent. We concluded there that corporate managers had the moral autonomy under the ALI Principles of Corporate Governance to spend corporate resources to save lives of non-customers. We now revisit that hypothetical to consider how a manager would analyze that situation under Catholic Social Teaching.

Grisez concluded in his analysis of the hypothetical that management should not undertake the philanthropy with corporate resources. ${ }^{153}$ In his view, management's first responsibilities are to the corporate stakeholders; those responsibilities limit management's freedom to help non-stakeholders. ${ }^{154}$ He concluded that the corporation

152. Id. at 91807.

153. GRISEZ, DifFICULT MORAL QUESTIONS, supra note 83, at 458.

154. Grisez defines stakeholders to include shareholders, managers, employees, regular suppliers and regular customers. He assumes that the corporation does not recognize any "gratuitous arrangement" for benefiting persons who do not contribute to the corporate welfare. One might suggest that in this age of "good corporate citizenship" virtually every publicly held company operates on the basis that stakeholders recognize such gratuitous arrangements since the effect of 
had a primary duty to its investors to provide them with a fair return, or, if investor returns already exceeded a market rate, to reduce its prices to its customer stakeholders or increase its payments to its vendor stakeholders. ${ }^{155}$ In short, he concluded that acts of humanitarian aid cannot be undertaken at the cost of violating a duty to another:

Even if one has charge of a unique capacity to meet a vital need, however, one may not use the capacity to meet the need if that would violate some prior responsibility. Parents of modest means, for example, may not donate part of the money they could use to meet any genuine need of their own children to famine relief that would save other children. ${ }^{156}$

Grisez's analysis presents an excellent example of how perspective can affect prudential judgment regarding application of Catholic Social Teaching to a specific situation. His starting point - that management's freedom is limited by its "responsibilities" to stakeholders ${ }^{157}$-assumes that managers' moral choices are constrained by both a particular duty to stakeholders and a view that the ethical duty to those stakeholders precludes any beneficial conduct to third parties in need. ${ }^{158}$ While not unreasonable, we do not believe it is necessary to construe the duty to stakeholders so narrowly. Even the ALI Principles of Corporate Governance recognize discretion in this respect. In other words, all stakeholders, in becoming involved with the corporation, incur the risk that management will take action that in one way or another interferes with the profits and costs connected to management's role within the corporation. Not even shareholders are entitled to specific funds of the corporation, and the business judgment rule permits management to hold the funds as cash. If stakeholders are not guaranteed any particular cost/benefit analysis as a matter of corporate law, their moral entitlement to hold management to a purely financial analysis is easily questioned. If management has a moral obligation to forego philanthropy, that

such arrangements, even if material, is but one factor affecting stakeholder investment decisions. GRISEZ, DIFFICULT MORAL QUESTIONS, supra note 83 , at $456-57$.

155. GRISEZ, DIFFICULT MORAL QUESTIONS, supra note 83, at 457-58.

156. GRISEZ, DIFFICULT MORAL QUESTIONS, supra note 83, at 458.

157. Grisez, DiffiCUlt Moral Questions, supra note 83, at 457.

158. This would seem to indicate that Grisez adopts a contractarian view of the corporation; otherwise no reason exists to conclude that management is not free to cause the corporation to act as any other legally cognizable person and take any action not otherwise illegal. $C f$. MODEL BUS. CORP. ACT $\S 3.04$ (2002) (corporation has power to take any action that an individual can take). In fairness, Grisez does assume that the business, under any theory, is organized for a limited specific good, which would certainly be uncharacteristic of the vast majority of American corporations and of virtually all publicly held corporations. See GRISEZ, DIFFICULT MORAL QUESTIONS, supra note 83 , at 454. 
obligation must arise outside of corporate law and the "rules of the community."

More fundamentally, Grisez's assessment seems to unnecessarily dilute the principles of solidarity and subsidiarity that lie at the base of Catholic Social Teaching. In our view, the questions are whether the corporation, as the sole efficient provider of the remedy, is permitted to undertake the philanthropy, or whether permissibility is negated, superseded, or tempered by the company's relationships with its investors/stakeholders or by its lack of relationship with the recipients of the modified drug.

We conclude that as long as sustainable long-term economic profitability is reasonably foreseeable, solidarity empowers the corporation to undertake philanthropic conduct because the corporation is, in fact, the most reasonable provider of that remedy. In response to Grisez's particular concerns, this principle holds even if the result prevents suppliers from being paid more for their raw materials, employees from obtaining increased wages, purchasers from paying less for the product, and investors from obtaining a greater return. ${ }^{159} \mathrm{We}$ believe that Catholic Social Teaching recognizes that the question of what constitutes a just cost, wage, and profit, and whether corporations ethically acquit themselves of their duties to stakeholders in these areas, need not prescind from the corporation or manager's right to engage in important works of humanitarian aid. Such a determination would involve a comparison to other corporations in similar lines of business. The primary consideration involved is whether the impact of a humanitarian decision would result in financial inequalities among stakeholders differing significantly from the financial relations found in similar corporations. Provided that the financial sustainability of the corporation is maintained, we believe it would be almost impossible for the economic impact of such conduct to be so detrimental to stakeholders that it would constitute a violation of the corporation's duty to them. In short, such a case presents an inverse of the usual application of subsidiarity. Just as a larger organization should not undertake activities that can be handled by a smaller unit of society, Catholic Social Teaching recognizes that large economic institutions are sometimes precisely the appropriate actor to address the needs of the marginalized.

Second, application of the principle of solidarity strongly supports corporate philanthropy in this case. A corporation does not have an obligation to help every person in need, but on what basis-other than profit maximization-can the corporation be denied a moral right to help 
a known person or group when the need is great and the corporation is in a proximate position to meet the need without at the same time undermining its financial sustainability? Grisez's invocation of "prior responsibility" seems exaggerated and at odds with the "golden rule" in this context. No reasonable manager would deny that if such a norm has any application in business, it must be applied with a sense of prudence and proportionality. Just as one could quibble about what constitutes a "genuine need" in Grisez's argument that a parent cannot donate to famine relief if it meant depriving her own child of a "genuine need," e.g., food versus soccer camp, we argue that corporate managers need not forego life saving philanthropy just because it might reduce shareholder returns or affect other stakeholders in significant, but not unfair, ways - assuming such action does not undermine long-term sustainability or grossly exaggerate costs to suppliers and consumers, wages, or shareholder returns.

In sum, Grisez's prudential judgment on this hypothetical is not unassailable. We conclude that, under Catholic Social Teaching, an individual who stood in the shoes of the corporation would have a right to provide the modified drugs and save lives. The Golden Rule would require that much. Because the essence of the corporation from the moral point of view is nothing more than a voluntary community of its investors, the community has the right to respond as an individual would, or at least could respond. Stakeholders should not be able to escape such moral options and challenges simply by ceding management of their money to fiduciaries, and fiduciaries should be free to make decisions that would be morally permissible for the community of stakeholders individually.

\section{Case 5: Employee Participation in Management}

Aaron's practices regarding managerial decision-making and delegation of authority have not changed since the 1950s. It is still primarily a "top-down" company where non-managerial employees have little or no say in how they perform their jobs or in how products are manufactured. Aaron's new Director of Transmission Products had great success in his former employment with empowering employees to create work teams that have substantial discretion as to all matters affecting their activities, including assembly procedures and work rules. He has proposed to his Vice President that the Division adopt the work team concept and permit employee participation in all of his management decisions. 


\section{Analysis:}

Papal comments support the idea of employee participation in management. Pope Pius XII, for example, in an address given in 1952, recognized that participation was an option, but not required:

In principle a right as such of co-management (co-determination) does not belong to the worker, but it is not forbidden for employers to make it possible for workers to participate in management in a certain form and to a certain extent, nor is the State prevented from giving the worker power to make his voice heard in the management of certain enterprises where the extraordinarily great accumulation of power in the hands of anonymous capital could, if left to itself, do manifest harm to the community. ${ }^{160}$

But later statements by the same Pope seem to make the matter more obligatory:

The economic and social function to which every man aspires requires that control over the way in which he acts be not completely subject to the will of another. The head of the undertaking values above all the power to make his own decisions. He anticipates, arranges, directs, and takes responsibility for the consequences of his decisions. His natural gifts ... find employment in his directing function and becomes the main means by which his personality and creative urge are satisfied. Can he [then] deny to his subordinates that which he values so much for himself? ... There is no question that for the common good, in a human conception of the enterprise, the authority of the manager ought to be protected, but no room can exist in such a conception for so damaging a denial of the profound worth of the employees of the enterprise. ${ }^{161}$

Foreshadowing the teaching of Vatican II, Pope John XXIII encouraged employee participation in management in his encyclical, Mater et Magistra:

We ... are convinced that employees are justified in wishing to participate in the activity of the industrial concern for which they work. It is not, of course, possible to lay down hard and fast rules regarding the manner of such participation, for this must depend upon prevailing conditions, which vary from firm to firm and are frequently subject to rapid and substantial alteration. But We have no doubt as to the need

160. Pius XII, in an address to The Italian Social Week, 1952 (quoted in Jean-Yves Calvez, Purpose of the Corporate Enterprise, available at http://www.stthomas.edu/cathstudies $/ \mathrm{cstm} /$ antwerp/p4.htm).

161. Pius XII, in an address to business managers in 1956 (quoted in Jean-Yves Calvez, Purpose of the Corporate Enterprise, available at http://www.stthomas.edu/cathstudies $/ \mathrm{cstm} /$ antwerp/p4.htm). 
for giving workers an active part in the business of the company for which they work - be it a private or a public one. Every effort must be made to ensure that the enterprise is indeed a true human community, concerned about the needs, the activities and the standing of each of its members.

... All this implies that the workers have their say in, and make their own contribution to, the efficient running and development of the enterprise...

Obviously, any firm which is concerned for the human dignity of its workers must also maintain a necessary and efficient unity of direction. But it must not treat those employees who spend their days in service with the firm as though they were mere cogs in the machinery, denying them any opportunity of expressing their wishes or bringing their experience to bear on the work in hand, and keeping them entirely passive in regard to decisions that regulate their activity. ${ }^{162}$

Finally, Gaudium et Spes confirms the papal statements that came before it:

In economic enterprises it is persons who are joined together, that is, free and independent human beings created to the image of God. Therefore, with attention to the functions of each-owners or employers, management or labor-and without doing harm to the necessary unity of management, the active sharing of all in the administration and profits of these enterprises in ways to be properly determined is to be promoted. ${ }^{163}$

Given these statements, there does not seem to be any question that a plan allowing some employee participation in Aaron's practices should be allowed-the question, though, is how much. The U.S. Bishops have this insight to offer:

Catholic social teaching has endorsed on many occasions innovative methods for increasing worker participation within firms. The appropriateness of these methods will depend on the circumstances of the company or industry in question and on their effectiveness in actually increasing a genuinely cooperative approach to shaping decisions. The most highly publicized examples of such efforts have been in large firms facing serious financial crises. If increased participation and collaboration can help a firm avoid collapse, why should it not give added strength to healthy businesses? Cooperative

162. Mater et Magistra, supra note 124, at qा 91-92 (emphasis added).

163. Gaudium et Spes, supra note 96, at ๆ 68. 
ownership is particularly worthy of consideration in new entrepreneurial enterprises. ${ }^{164}$

How persuasive is this teaching? Interestingly, one of the few detailed critiques of Catholic Social Teaching in the corporate law literature addresses employee participation. In his 1998 Gianella Lecture at Villanova Law School, Professor Stephen Bainbridge considered the pronouncements of John Paul II in concerning whether and to what extent workers should participate in management. In particular, Professor Bainbridge's critique dealt with the limitations imposed upon managerial discretion by the profit maximization criterion. ${ }^{165}$ An analysis of the critique asserted in the lecture is instructive both for this hypothetical and for the general approach adopted here because of its opposition to fundamental aspects of Catholic notions of the dignity of human labor and teachings regarding the rights that flow from the obligation of the corporation to seek the common good of its members.

The Gianella Lecture commenced with an assertion of skepticism concerning John Paul II's arguments in favor of employee participation in management:

If Pope John Paul II is correct, employee involvement should enhance employee morale. In turn, workers empowered by participation rights should be more productive than alienated workers denied such rights. Neither seems to be the case. I have reviewed the relevant empirical literature in detail elsewhere. Suffice it to say that there is no conclusive documentation that employee involvement consistently leads to long-term economic benefits. ${ }^{166}$

As a zealous advocate for his position, Bainbridge carefully words his conclusion: He would require conclusive documentation that employee involvement consistently leads to long-term economic benefits. To this formulation, there are at least three responses. The first is obvious-for what proposition in management "science" is there conclusive documentation of consistent results across firms, industries,

164. Economic Justice for All, supra note 132, at $\mid 301$.

165. Stephen M. Bainbridge, Corporate Decisionmaking and the Moral Rights of Employees: Participatory Management and the Natural Law, 43 VILL. L. REV. 741 (1998). Professor Bainbridge discusses the issue in the context of government mandated employee participation. Although that is not the issue presented by our case, the criticisms of Catholic Social Teaching discussed in the text would apply equally here. It should also be noted that much of his lecture deals with prudential arguments for and against mandated employee participation. To the extent that the government imposes participation on those who do not want it (whether owners, existing managers, or employees), Bainbridge is undoubtedly correct that costs of decision-making will be increased without commensurate benefit from employee participation. Bainbridge cites approvingly but without discussion to this article in his later AAA.

166. Id. at 761 . 
eras and cultures? Second, "economic" benefit is hardly the sole, if even primary, yardstick by which Catholic Social Teaching would measure participatory management. Third, Bainbridge's insertion of his own suppositions in analyzing the papal teaching skews his conclusion.

As discussed above, Catholic Social Teaching is not concerned solely, or even primarily, with promoting employee productivity and economic benefit, and it does not necessarily follow that happier, more fulfilled employees are more productive. Indeed, happiness may lead an employee to conclude that the nose to the grind wheel is not the best posture in life, and that employee participation may lead to seemingly inefficient decisions that support a more meaningful life for employees. For example, employee participation in management may lead to a conclusion that mothers in the work force should be allowed to take time during the day to breastfeed their children in the company day care center. Depending on how productivity is measured, such a decision could lead to less output by women workers during a given period and over a long-term period. On the other hand, it could also result in longer term productivity through employee retention or improved quality through increased employee experience. Similarly, employee participation in decisions regarding product design or manufacturing processes could result in a loss of short-term productivity if measured by units per time or revenue per employee, but nevertheless may also result in intangible or longer-term benefits resulting from improved employee morale, production of higher quality goods, and reduced employee attrition. ${ }^{167}$ The possibility of decreased productivity, while a significant factor in a business decision, is insufficient, standing alone, to ethically analyze the practice.

In addition, Bainbridge disagrees with the basis for the Catholic view of the significance of work in the economy of salvation:

Surely Pope John Paul II overstated the case, however, when he opined that work is the "essential key" to the "whole social question." There is no scriptural basis for that claim. To the contrary, insofar as the Pope's arguments rely on humanity's status as cocreator with God, those arguments are entirely nonscriptural. Humans may (and should) imitate God's creative work, but people do not share in God's work as creator. In the Genesis account, creation was completed on the sixth day. That is exactly why God could call it good and "rest" on the seventh day. Instead of being part of an ongoing process of creation, work was a direct result of the fall--when exiled from Eden, humans

167. In any event, substantial evidence exists that Bainbridge's conclusion is inconsistent with reality. See, e.g., RiCHARd B. FreEMAN \& JoEl Rogers, What WORKERS WANT 66 (1999). 
were condemned to "painful toil." Work was thus not intended to be intrinsically fulfilling, but simply a necessary means of survival. ${ }^{168}$

These critiques miss the point. First, Bainbridge begins by attacking what is for Catholics a straw man - the Scriptural basis for the teaching. Not every truth of the natural law is explicitly laid down in Scripture, and Catholic Social Teaching does not profess to be solely dependent upon Scripture for its validation. Therefore, the mere fact that a particular principle is not derived from Scripture does not mean that it is invalid. ${ }^{169}$ In fact, it is its natural law basis that gives much of Catholic Social Teaching a claim to set standards applicable to non-Christian persons of goodwill, who are also bound by the natural law. ${ }^{170}$

Bainbridge's claim that John Paul II overstated the creative role of man also misses the point, since it appears to be based on a simple misreading of the meaning of "create" in Catholic teaching. It is true that man does not create in the sense that "to create" is to make something from nothing- "ex nihilo." Thomas Aquinas, for example, teaches that "creation is the proper act of God alone ... [I]t is impossible for any creature to create, either by its own power, or instrumentally."171 However, creation has been long understood to have a broader, metaphorical sense. Thus, in response to Augustine, who asserted that to create is to make something by bringing forth something from what was already, Aquinas replies: "Augustine uses the word creation in an equivocal sense, according as to be created signifies improvement in things ... We do not however speak of creation in that way here." ${ }^{172}$ In short, it is obvious that man cannot, in an absolute sense, create something from nothing, but this is not the sense that Pope John Paul II intends. Rather, he uses the word creation in the same way Augustine used it; namely, man is able to create by improving or converting the

168. Bainbridge, supra note 165 , at 762 (citations omitted).

169. Bainbridge, supra note 165 , at 747 . Bainbridge conceded that "the relevant papal encyclicals ... purport to state natural law principles applicable to all," not only revealed truths addressed to Bible-reading Christians.

170. Bainbridge addressed Catholic Social Teaching precisely because it is not limited to doctrinal statements of interest only to "Roman Catholic capitalists and laborers." Bainbridge, supra note 165 , at 747 . In this context, the Church observes that its teaching draws not only upon scriptural sources for its truths but upon any legitimate body of human knowledge:

The Church's social doctrine avails itself of contributions from all branches of knowledge, whatever their source, and has an important interdisciplinary dimension. "In order better to incarnate the one truth about man in different and constantly changing social, economic and political contexts, this teaching enters into dialogue with the various disciplines concerned with man. It assimilates what these disciplines have to offer." CSDC at 76 (quoting Centesimus Annus, supra note 98, at 958).

171. Thomas Aquinas, Summa Theologiae, I, Question 45, Article 5, Obj. 3.

172. Thomas Aquinas, Summa Theologiae, I, Question 45, Article 1, Reply to Obj. 1. 
natural goods of the earth into something useful through work. In this way, man is able to participate in the work of creation. ${ }^{173}$

Bainbridge's third criticism of John Paul II's approach is that work is not intended to be "fulfilling" but, as a direct result of original sin, is "simply a necessary means of survival." ${ }^{174}$ Bainbridge's criticism rests in part on terminology, since he equates work with "painful toil." 175 However, the divine command to work was already in existence before the biblical Fall: "[God] took the man and put him in the Garden of Eden to till it and keep it." ${ }^{, 176}$ Although original sin was the cause of work becoming arduous and tiring, work in itself, as an expression of the good of human nature, was a part of the biblical plan for the human person from the beginning, and is a means by which persons achieve fulfillment in either a pre- or post-lapsarian dispensation. Work was necessary that man might eat, have shelter, form community, etc., but inasmuch as these specific goods are necessary goods for human persons to live and act, and because such goods can only be attained through the process of work, work is a means for man's natural perfection. ${ }^{177}$

Even if Bainbridge were correct in equating work with "painful toil," work is still an essential part of the social question because, from a theological perspective, it is by means of toilsome work that human persons are configured to the work of redemptive suffering of the New Adam, Christ, and therefore to supernatural perfection. According to the Catechism of the Catholic Church:

[Work] can also be redemptive. By enduring the hardship of work in union with Jesus, the carpenter of Nazareth and the one crucified on Calvary, man collaborates in a certain fashion with the Son of God in his redemptive work. He shows himself to be a disciple of Christ by carrying the cross, daily, in the work he is called to accomplish. Work can be a means of sanctification and a way of animating earthly realities with the Spirit of Christ. ${ }^{178}$

173. CCC, supra note 139, at ๆ 2460 : "The primordial value of labor stems from man himself, its author and beneficiary. By means of his labor man participates in the work of creation."

174. Bainbridge, supra note 165 , at 762 .

175. Note that we often speak of work as fulfilling in the sense that it is an enriching and pleasurable experience. If work were not intended by God to be something more than painful toil, why would we see so many people who have the means to survive without working, from highly paid CEOs to "trust-baby" heirs, engaged in meaningful labor?

176. Genesis 2:15; CSDC at १ा 255-56.

177. See, e.g., ThOMAS Aquinas, Summa TheOlogiaE, II, Question 4, Article 7: "For ... happiness as can be had in this life, external goods are necessary . . by serving as instruments to happiness, which consists in an operation of virtue."

178. CCC, supra note 139, at $\{2427$. 
In short, even if Bainbridge had been correct in characterizing work as merely a "necessary means of survival," it does not follow that workers should not have a right to participate in decisions that affect their means of survival. Rather, as the Catechism teaches, "[i]n work, the person exercises and fulfills in part the potential inscribed in his nature." 179 It is precisely because work is necessary to attain certain goods for man's nature that he should have a right to participate in decisions affecting that work.

Finally, Bainbridge addressed both the empirical basis of the Church's teaching and its relationship with post-modern culture and individual alienation:

As to the assumption made by Catholic Social Teaching with regard to human nature, Pope John XXIII asserted that as workers become more educated they desire "to assume greater responsibility in their own sphere of employment." Pope John Paul II likewise assumed that the individual worker wishes "to take part in the very work process as a sharer in responsibility and creativity."

... I believe that these empirical claims are, at best, over-stated. Some workers demonstrably prefer hierarchical workplaces where decision-making is reserved to management over workplace democracy....

Proponents of the papal position might dismiss such workers as being unable to recognize their own needs. Such an argument appears to be implicit in Pope John Paul II's assertion that someone "is alienated if he refuses to transcend himself and to live the experience of self-giving and of the formation of an authentic human community oriented toward his final destiny, which is God." This papal dictum smacks of the Aristotelian error of monoistic perfectionism, which is the view that there is one supremely valuable way of life. Indeed, the pope appears to make the same error for which he condemned socialism; namely, the belief "that the good of the individual can be realized without reference to his free choice." 180

Bainbridge's arguments can be dismissed for the following reasons: First, his argument is weakened by scholarly literature demonstrating that

179. CCC, supra note 139, at 2428.

180. Bainbridge, supra note 165 , at $763-64,768$. Bainbridge's comparison of papal teaching to Aristotle's "error" of monoistic perfectionism adds nothing to his critique. First, it is virtually impossible to construe the Pope's words to fit Bainbridge's interpretation. The quoted language does not even remotely deal with the value of a given lifestyle (e.g., Aristotle's ideal contemplative life). Rather John Paul II is simply recognizing that man is susceptible, in the context of all economic systems, of reversing the means and ends of human life. The proper end is not conformity with a "purely human plan of reality." Centesimus Annus, supra note 98, at 142. 
most workers do in fact desire increased participation. ${ }^{181}$ Second, his reliance on empirical studies is a non sequitur: The claim that employee participation ought not to be offered because "some workers demonstrably prefer hierarchical workplaces" does nothing to undermine the value of the right. The point is not whether people would actually choose to exercise the right to participate, but whether the right is one which persons are entitled to exercise if they so choose. Following the logic of the argument of Bainbridge's lecture would lead to the conclusion that Americans should not have a right to vote because most persons eligible to vote do not do so.

Further, even if Bainbridge's premise that a right to participate should exist only to the extent that workers would in fact participate, empirical studies based on current employee desires could be seriously misleading. Even if rights depended on the value the majority places on them, it is unlikely that studies based on current workplace environments would accurately measure that value. Such studies are likely to be influenced by fairly cynical market views of both management and labor regarding the effectiveness of participation, and we would expect to see workers respond that participation is not a priority for them. The Pope, however, is writing about a community in which workers' relationships with owners are governed by a respectful paradigm of solidarity. In that context, we would presumably expect to see workers favor the right even if they personally did not feel the need to exercise the franchise.

If Aaron's Vice President is not persuaded by Bainbridge's critiques, what should he do? Applying the foregoing principles, the Vice President could reasonably conclude that the employees should, as a matter of business ethics, have a say in making decisions that impact their day-to-day activities, such as assembly procedure and work rules. Whether they should be given an even greater responsibility to make decisions on long-term policy and business matters is more difficult to discern from Catholic Social Teaching. Many workers do not have the training or education in problem-solving skills to make sound decisions in this area. It is also arguable that too much employee participation will divide the unity necessary for management of the company. To quote John XXIII: "Any firm which is concerned for the human dignity of its workers must also maintain a necessary and efficient unity of direction." ${ }^{182}$ Consequently, employee participation in all management decisions does not seem to be required by Catholic Social Teaching, and

181. See, e.g., FREEMAN \& ROGERS, supra note 167, at $41-42$ (stating that $63 \%$ of all workers surveyed wanted more influence at the workplace, while $35 \%$ wanted to keep things the way they are).

182. Mater et Magistra, supra note 124, at ๆ $91-92$. 
may in fact conflict with the unity and sphere of competence of managerial direction.

Accordingly, the Vice President is left with a prudential judgment as to what level of participation by employees will best redound to the common good while recognizing the inherent dignity of the employees. Perhaps the most prudential judgment will reflect on the Director's experience. To the extent that the proposed changes have led to successful operations in the past, it would seem that Catholic social thought would counsel adoption of a similar proposal at Aaron. Employee participation is a good to the extent that employees are actually likely to participate, and to the extent that previous experience indicates that the proposed level of participation is unlikely to exceed the employees' sphere of competence or otherwise conflict with overall managerial direction.

\section{CONCLUSION}

We have argued that corporate managers have the autonomy and responsibility to take ethical considerations into account in their business decisions regardless of the common perception that the manager's only duty is to maximize profits. We have no pretensions that we have destroyed the wealth maximization myth, but we did not need to. The American Law Institute and our publicly held corporations have already departed from it, regardless of whether doing so was theoretically sound or good public policy. ${ }^{183}$ To the extent that statutes and legal decisions treat corporations as separate legal persons, they are presumably subject to the same ethical rights and restraints as other members of society. ${ }^{184}$ Even if the corporation is viewed as a nexus of contracts, there is no reason to believe that those contracts should be viewed as excluding the "morals clause" inherent in the corporation's public disclosures and the minimal restrictions imposed by relevant corporate law.

In short, the Manager's Dilemma is a false one: The choice is not sound business or ethical conduct. Rather, the Manager's responsibility is to exercise prudential judgment to increase the likelihood that the common good of those affected by the corporation will be furthered without contradicting the corporation's representations to its investors regarding legitimate financial returns.

The real issue facing the Manager, then, is how to analyze the ethical issues presented by a given business situation. We have suggested that Catholic Social Teaching provides workable principles that will 
guide the exercise of prudential judgment toward the furthering of the common good. Though we do not contend that these principles will be accessible or agreeable to all at first blush, each is consistent with rationally defensible judgments about the human good, even where they may be expressed in a theological or Scriptural context.

Finally, it is clear from our consideration of specific examples that application of Catholic Social Teaching does not always admit of only one possible resolution to a given business policy. Indeed, the fact that the flexibility of that teaching allows differences of opinion demonstrates its value as a lens for examining ethical issues in business. The principles are sufficiently nuanced to preclude shallow, unrealistic responses, yet focused enough to allow meaningful debate and supportable decisionmaking with respect to a wide variety of possible alternatives respecting both economic and other human goods. 